\title{
Türkçe Öğretmeni Adaylarının Üst Bilişsel Okuma Stratejilerinin Okuma Motivasyonu Üzerindeki Etkisinde Sınıf Düzeyinin ve Cinsiyetin Rolü
}

\author{
The Role of Grade Level and Gender on Reading Motivation of Metacognitive \\ Reading Strategies of Prospective Turkish Teachers
}

Yasemin BAK $\dot{I}^{*}$

\begin{abstract}
Öz
$\mathrm{Bu}$ araştırmada, Türkçe öğretmeni adaylarının üst bilişsel okuma stratejilerinin, okuma motivasyonu üzerindeki etkisinde sınıf ve cinsiyet değişkenlerinin rolü yapısal eşitlik modellemesiyle incelenmiştir. İlişkisel tarama modeliyle desenlenen araştırmada, basit seçkisiz örnekleme yoluyla oluşturulan çalışma grubu; Türkçe Öğretmenliği Bölümünde öğrenim gören 209 öğretmen adayından oluşmaktadır. Verilerinin toplanmasında Çöğmen ve Saracaloğlu (2010) tarafından Türkçeye uyarlanan "Üst Bilişsel Okuma Stratejileri Ölçeği” ile Yıldız, Yıldırım, Ateş ve Çetinkaya (2013) tarafından Türkçeye uyarlanan "Yetişkin Okuma Motivasyonu Ölçeği” kullanılmıştır. Veriler yapısal eşitlik modellemesiyle çözümlenmiş olup, verilerin analizlerde SPSS 23 ve AMOS 22.0 yazılımları kullanılmıştır. Katılımcıların üst bilişsel okuma stratejilerinin, okuma motivasyonu üzerindeki etkisinde sinıf ve cinsiyetin rolünün incelenmesine dair oluşturulan modellere ilişkin parametrelerin tahminde maksimum olabilirlik (Maximum Likehood) yöntemi tercih edilmiş, $\chi^{2} / \mathrm{df}$, CFI, GFI, TLI, NFI, IFI, RMSEA ve SRMR uyum indeksleri kullanılmıştır. Araştırma sonucunda hipotez modellerin tümünün geçerli olduğu; üst bilişsel okuma stratejilerinin, okuma motivasyonun \%20'sini açıkladığı tespit edilmiştir. Bunun yanı sıra üst bilişsel okuma stratejileri 1, 2, 3 ve 4 . sınıfta sırasıyla $\% 23, \% 14, \% 13$ ve \%31'ini; kadın ve erkek öğretmen adaylarına ilişkin modellerde ise sırasıyla \%3’ünü ve \%52'sini açıkladığ 1 belirlenmiştir. $\mathrm{Bu}$ araştırma sonucunda üst bilişsel okuma stratejilerinin, okuma motivasyonun artışında önemli bir yordayıcı olduğu söylenebilir.
\end{abstract}

* Dr. Öğr. Üyesi., Recep Tayyip Erdoğan Üniversitesi, Eğitim Fakültesi Türkçe ve Sosyal Bilimler Eğitimi Bölümü, E-posta: ysmnbaki@gmail.com, Orcid ID: https://orcid.org/0000-0003-4064-3724 
Anahtar kelimeler: Okuma üst bilişsel stratejileri, okuma motivasyonu, Türkçe öğretmeni adayları, cinsiyet, sınıf düzeyi, yapısal eşitlik modellemesi.

\begin{abstract}
In this study, the role of grade and gender variables on reading the motivation of metacognitive reading strategies of prospective Turkish teachers was analyzed by structural equation modeling. In the study designed by the relational screening model, the study group which was formed by simple random sampling consisted of 209 prospective teachers who were studying at Turkish Language Teaching Department. "Adult Reading Motivation Scale" adapted to Turkish by Yildiz, Yildirim, Ates and Cetinkaya (2013) and "Metacognitive Reading Strategies Questionnaire" adapted to Turkish by Cogmen and Saracaloglu (2010) were used in the collection of data. Data were analyzed by structural equation modeling and SPSS 23 and AMOS 22.0 software were used in the analysis of data. The maximum likelihood method was preferred to estimate the parameters related to the models formed for analyzing the role of grade level and gender of the participants' metacognitive reading strategies on reading motivation and $\chi^{2} / \mathrm{df}$, CFI, GFI, TLI, NFI, IFI, RMSEA and SRMR fit indices were used. As a result of the research, it has been determined that all of the hypothesis models were valid and metacognitive reading strategies revealed $20 \%$ of reading motivation. In addition, metacognitive reading strategies revealed $23 \%, 14 \%, 13 \%$, and $31 \%$ of reading motivation on the grades of $1 \mathrm{st}, 2 \mathrm{nd}$, 3rd, and 4 th, respectively; and $3 \%$ and $52 \%$ of it for the models related to female and male prospective teachers. As a result of this research, it can be said that metacognitive reading strategies are important predictors of the increase in reading motivation.
\end{abstract}

Keywords: metacognitive reading strategies, reading motivation, prospective Turkish teacher, gender, grade level, structural equation modeling.

\title{
Giriş
}

Okuma; zihinsel olarak özgürleşmek ve insan olduğunu idrak etmek için kendisine verilen yaşam denilen süreci anlayıp kavramasını ve sahip olduğu tüm becerilerin açığa çıkarılmasını sağlayan en temel araçtır (Güneș, 2007). Bilișsel, duyuşsal ve devinișsel boyutların iç içe geçtiği karmaşık bir süreç olan okuma temelde etkileşimli bir anlama ve yorumlama süreci (Günay, 2003) olmakla birlikte aynı zamanda bir duyu edinimidir olup bireyin kendini ve çevresini okuyarak anlamlandırma sürecidir (Manguel, 2004). Dolayısıyla okuma davranışının kazanılması ve sürdürülmesinde bilișsel ve devinişsel faktörlerin yanı sıra duyuşsal faktörün de önemli bir etkisi bulunmaktadır. Davranışın süreklilik kazanmasında etken eden önemli faktörlerden biri olan motivasyon (Komiyama, 2013), öğrenme sürecini doğrudan etkileyen (Corbin, 2008) çok boyutlu duyuşsal bir değişkendir (Watkins ve Coffey, 2004). Okuma motivasyonu ise okuyucuyu harekete geçiren algı ve değerler sisteminin birleşerek oluşturduğu itici güç olarak tanımlanmaktadır (Unrau ve Quirk, 2014). Yapılan araștırmalar okuma motivasyonunun, okuma eyleminin tekrarında ve okuduğunu anlamanın gerçekleşmesinde oldukça önemli bir etkiye sahip olduğunu ortaya koymaktadır (Guthrie, Wigfield, Humenick, Perencevich, Taboada ve Barbosa, 2006; Yildız, 2013). Dhanapala ve Hirakawa (2016)'nın araștırmasında okuma motivasyonun metnin anlaşılmasının \%38’ini açıkladığını, Schaffner ve diğerlerinin (2013) araştırmasında da içsel 
ve dişsal motivasyon eş zamanlı olarak sürece dahil edildiğinde okuma miktarı ve okuduğunu anlamaya anlamlı bir şekilde katkı sağladığını ve okuma miktarının \%69'unu açıkladığını tespit etmiştir. Özetle okuma motivasyonu, okuma sürecinde anlamı oluştururken kullanılan bilişsel süreçlerle de yakından ilişkili olmakla birlikte bu süreçte kullanılan stratejileri de en yetkin şekilde kullanabilmenin motivasyonu olarak da değerlendirilmektedir (Guthrie ve Wigfield, 2000).

\section{Üstbilisssel okuma stratejileri}

Okumanın nihai amacı anlamanın gerçekleşmesidir ki yapılan araştırmalar okuma sürecinde strateji kullanıldığında anlamanın daha iyi gerçekleştiğini ortaya koymaktadır (BoulwareGooden, Carreker, Thornhill ve Joshi, 2007; Bang ve Zhao, 2007; Çakıroğlu, 2007; Hall ve Bowmann, 1999; Öztürk ve Uzunkol, 2015; Saraç, 2011; Sen, 2003). Okuma sürecinde kullanılan stratejiler, okuduğunu anlamayı geliştiren faktörlerden sayılmaktadır (Anastasiou ve Griva, 2009; Temizkan, 2007; Temizkan, 2008; Weir, 1998) Okuma esnasında stratejik okuma davranışının kazanılması bilişsel süreçlerin farkında olunmasını sağlamaktadır (Caron, 1997). Bilişsel farkındalık becerileri Türkçe dersinde tutumu da olumlu yönde etkileyerek okuduğunu anlama başarısını ve kalıcılığı arttırmaktadır (Gelen, 2003).

Biliş hakkında bilgi, biliş sürecini kontrol ve düşünmeyi düşünme gibi çeşitli kavramlarla karşılanan üstbiliş (Başaran, 2013; Blakey ve Spence, 1990), okuma sürecinde metnin anlamlandırabilmesi için bilişsel süreçlerin farkında olunması ve stratejik okuma davranışının edinimidir (Caron, 1997; Öztürk ve Uzunkol, 2015). Bir başka söylemle okuma sırasında okuyucunun anlamayı kolaylaştırmak için kullandığı stratejilerdir (Daniel ve Steineke, 2004). Okuma üstbilişsel stratejileri ise okuyucunun; bu süreçte üstbilişsel bilgisini kullanarak okuma davranışını izlemesi ve düzenlemesidir (Bozkurt, 2013). Kısaca metni anlamanın da ötesine geçerek metni yeniden yaratarak metinden orijinal ve yeni anlamlar çıarabilen ileri düzey okurların kullandığı zihinsel taktikler koleksiyondur (Mert, 2015). Bu stratejiler okuduğunu anlama sırasında ve sonrasında, eksikliklerinin ve düzenlemelerinin farkında olmayı sağlayarak okumanın temel amacı olan okuduğunu anlama düzeyinde tamamlayıcı öge işlevi görmekte (Bang ve Zhao, 2007) ve okuduğunu anlama düzeyini arttırmaktadır (Başaran, 2013; Baydık, 2011; Bozkurt, 2013; Butler, Cartier, Schnellert, Gagnon ve Giammarino, 2011; Çakıroğlu, 2007; Çakıroğlu ve Ataman, 2008; Çiçekçioğlu, 2003; Eker, 2014; Guo ve Roehrig, 2011; Riany, 2010; Saraç, 2010; Winne, 2001). Okuma sürecinde anlamayı kolaylaştıran üstbilişsel stratejiler (Daniel ve Steineke, 2004) okumayla ilgili hedeflere ulaşmada yardımcı bir etki oluşturmakta (Aarnoutse ve Schellings, 2003) ayrıca okuma zorluklarını azaltma ve okuma performansını geliştirmekte (Çakıroğlu, 2007; Çiçekçioğlu, 2003; Wright ve Jacobs, 2003) ve akademik başarının artışına da katkı sağlamaktadır (Ormrod, 2003; Young ve Fry, 2008).

\section{Değişkenler arası kavramsal ilişski}

Öğrenmenin temel ilkelerinden olan motivasyon kavramı dikkat, tutum ve bilişsel farkındalık kavramlarıyla ilişkili duyuşsal bir niteliktir (Gelen, 2004). Motivasyona etki eden faktörler arasında bu süreçte kullanılan stratejiler ve yöntemlerdin yanı sıra (Sarı ve Akınoğlu, 2009) bilişsel 
farkındalık becerilerine sahip olma da motivasyonu arttırıcı etkenler arasında yer almaktadır (Demir-Gülşen, 2000). Düşünmenin duyuşsal niteliklerini ve bilişsel bilgi düzeyini arttırmada kullanılan bilişsel beceri olan üstbiliş de motivasyonla ilişkilidir (Mokdari ve Reichard, 2002). Bir diğer yandan duyuşsal değişkenleri göz ardı ederek üstbilişsel niteliklere ilişkin yapılacak araştırmaların bütünün anlaşılmasında eksik kalacağından hareketle, bu durum motivasyon araştırmalarına yoğunlaşılmasının yanı sıra bilişsel süreçler ve motivasyon arasındaki ilişkilerin incelenmesine ilişkin de önemli adımlar atılmasını sağlamıştır (Yıldızlı ve Saban, 2015).

Bilişsel, duyuşsal ve devinişsel boyutlardan oluşan okuma eyleminde de asıl gaye olan anlamın açığa çıkması olup bu gayeye ulaşmak için birçok yöntem, teknik ve strateji kullanımı gereklidir (Alvermann, 2009). Bir yönüyle bilişsel becerileri kapsayan okuma bir başka yönüyle de güdüsel süreçleri de içermektedir. Başka bir söylemle çok boyutlu bir süreç olan okuma eyleminde bilişsel ve güdüsel süreçlerin eş zamanlı olarak işe koşulması gerekmektedir (Guthrie ve Wigfield, 2005). Bu değişkenler tek başına okumayı etkiledikleri gibi birbirleriyle etkileşime girerek de okuma üzerinde etki oluşturmaktadırlar. Okumayı etkileyen güdüsel değişkenlerden biri okuma motivasyonu olup bu değişkene etki etmekle birlikte okuma sürecinin bilişsel düzeydeki etkilerinin açığa çıkmasını sağlayan araçlardan biri de okuma stratejilerdir (Cantrell, Almasi, Rintamaa ve Carter, 2016; Topuzkanamış ve Maltepe, 2010). Yapılan araştırmalar okuma stratejilerinin kullanımıyla okuma motivasyonu arasındaki pozitif ilişkinin varlığını ortaya koymaktadır (Cantrell, vd., 2016; Nishino, 2007; Sani, Wan Chick, Awg Nik ve Raslee, 2011).

Genel okuma stratejileri okuma için hazırlık aşaması olarak değerlendirilirken, metnin ileri düzeyinde okuması, üst düzeyde anlamlar çıkarma ve çeşitli değerlendirmeler yapabilmek için asıl önemli faktör üstbilişsel stratejilerdir (Mokhtari ve Reichard, 2002). Meniado (2016) tarafından yapılan araştırmada üstbilişsel okuma stratejilerinin kullanımıyla okuma motivasyonu arasında pozitif yönlü bir ilişki olduğu, okuma motivasyonu ve üstbilişsel okuma stratejileri arasında pozitif yönde bir ilişki olduğu ortaya konulmuştur. Üstbilişsel farkındalık ve okuma motivasyonu arasındaki ilişkinin incelendiği çeşitli örneklem düzeyindeki araştırmalarda da bu iki değiş̧ken arasında pozitif yönde bir ilişki olduğu tespit edilmiştir (Bozkurt, 2013; Öztürk, 2012; Öztürk ve Uzunkol, 2015; Roeschl-Heils, Schneider, Van Kraayenoord, 2003; Wang, 2009). Alan yazında motivasyon ve üstbilişin okuduğunu anlama üzerindeki etkisine ilişkin sonuçlardan hareketle bilişsel bir eylem olan okuma sürecindeki üst/bilişsel beceri ve stratejilere ilişkin araştırmaların önemi son dönemde gittikçe artmaktadır (Jamshidi ve Moghaddam, 2013; Öztürk, 2012; Öztürk ve Uzunkol, 2015).

Yapılan araştırmalar üstbilişsel strateji eğitiminin, okuma becerisinde ve öğrenci başarısı üzerinde etkili bir faktör olduğunu göstermektedir (Dilci ve Kaya, 2012; Muhtar, 2006; Razi, 2010). Ancak öğrencilerin üstbilişsel stratejileri bildikleri ama kullanmadıkları ve bu süreçte öğretmenin rehberliğine ihtiyaç duymaktadırlar (Mayer, 1987). Bu süreçte öğretmenin, öğrencileri stratejik hale getirmesi, okumaya ilişkin değişen taleplerine nasıl tepki verebileceklerini bilmesinin yanı sıra öğrencileri sürekli izlemesi ve değerlendirmesi gerekmektedir (Cantrell vd., 2016). Dahası okuma sürecinde kalitenin arttırılmasında öğrencilerin üst düzeyde düşünme gelişimlerinin sağlaması için öğretmenlerin öğrencileri profesyonel olarak desteklemeleri gerekmektedir (De 
Naeghel, Van Keer ve Vanderlinde, 2014). Pressley (1990)'ye göre öğrenme sürecinin yetkin işleyişinin kalbinde yer alan değerli becerilerden olan bilişsel stratejilerin kullanımı ve bu stratejilerin kullanımına ilişkin motivasyonlarını arttırmak için öğretmenlerin farkındalıklarının geliştirilmesi gerekmektedir. Bu özelliklerin gelişimiyle öğretmenlerin doğrudan ya da dolaylı olarak okuma sürecinde öğrencilerin üstbilişsel strateji kullanımına ortam hazırlamalıdırlar (Housand ve Reis, 2008; Özcan, 2007).

Türkçe öğretmeni adaylarının okuma stratejilerini kullanımında diğer branşlara göre daha üst düzeydedirler (Karasakaloğlu vd., 2012; Topuzkanamış ve Maltepe, 2010). Bununla birlikte öğretmen adaylarının (Akif ve Alver, 2011; Aybek ve Aslan, 2016; Babacan, 2012; Çöğmen, 2008) ve Türkçe öğretmeni adaylarının üst bilişsel okuma stratejilerini sıklıkla kullandıkları tespit edilmiştir (Çeçen ve Alver, 2011). Ayrıca yapılan araştırmalarda Türkçe öğretmeni adaylarının üstbilişsel okuma stratejilerini kullanım düzeyleri ile kitap okuma alışkanlıkları (Edizer-Çetinkaya, 2015), öğretmen adaylarının üstbilişsel farkındalık düzeyleri ile problem çözme becerileri (Kışkır, 2011) ayrıca üstbilişsel okuma stratejileriyle ders çalışma stratejileri (Karasakaloğlu, 2012) arasında pozitif bir ilişki olduğu tespit edilmiştir. Karasakaloğlu, Karacaloğlu ve Özelçi (2012)'nin araştırmasında ise üst bilişsel ve motivasyonel becerilere sahip olan Türkçe öğretmeni adaylarının üst bilişsel okuma stratejilerini başarılı bir şekilde kullandıkları tespit edilmiştir. Bu çalışmalardan hareketle üstbilişsel stratejilerin gerek eğitim sürecinde gerekse okuma sürecindeki değişkenlerle pozitif ilişkilere sahip olduğu görülmektedir. Ancak yapılan alan yazın taramasında mevcut önemine rağmen Türkçe öğretmeni adaylarının üstbilişsel okuma stratejileri kullanımlarının okuma motivasyonu üzerindeki etkisini, bu etkide sınıf düzeyi ve cinsiyetin rolünün birlikte işe koşulduğu herhangi bir araştırmaya erişilmemiştir. Öğretmen adayları üzerinde bu iki değişkenin etkileşiminin incelenmesi hem akademik eğitimleri hem de öğretmenlik deneyimlerine ilişkin önemli katkılar sağlayacağı düşünülmektedir.

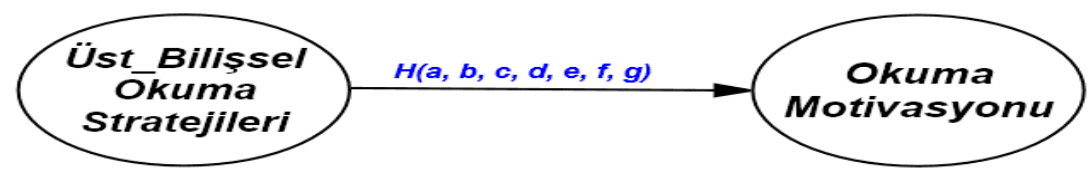

Şekil 1. Araştırma modeli

Yukarıdaki araştırma modeli çerçevesinde bu araştırmada Türkçe öğretmeni adaylarının üst bilişsel okuma stratejilerinin, okuma motivasyonlarına etki düzeyi ve bu etkide sınıf ve cinsiyetin rolünün tespit edilmesi amaçlanmıştır. İlgili modelleri test etmek üzere önerilen hipotezler aşağıda sunulmuştur.

$\mathbf{H}_{1}$ : Türkçe öğretmeni adaylarının üst bilişsel okuma stratejileri, okuma motivasyonunu manidar düzeyde yordamaktadır. 
$\mathbf{H}_{2}$ : 1. sınıf düzeyinde üst bilişsel okuma stratejileri, okuma motivasyonunu manidar düzeyde yordamaktadir.

$\mathbf{H}_{3}$ : 2. sınıf düzeyinde üst bilişsel okuma stratejileri, okuma motivasyonunu manidar düzeyde yordamaktadir.

$\mathbf{H}_{4}$ : 3. sınıf düzeyinde üst bilişsel okuma stratejileri, okuma motivasyonunu manidar düzeyde yordamaktadir.

$\mathbf{H}_{5}$ : 4. sınıf düzeyinde üst bilişsel okuma stratejileri, okuma motivasyonunu manidar düzeyde yordamaktadir.

$\mathbf{H}_{6}$ : Kadın öğretmen adaylarının üst bilişsel okuma stratejileri, okuma motivasyonlarını manidar düzeyde yordamaktadır.

$\mathbf{H}_{7}$ : Erkek öğretmen adaylarının üst bilişsel okuma stratejileri, okuma motivasyonunu manidar düzeyde yordamaktadır.

\section{Yöntem}

\section{Araștırmanın Modeli}

Türkçe öğretmeni adaylarının üst bilişsel okuma stratejilerinin, okuma motivasyonu üzerindeki etkisi ve açıklama oranın yanı sıra bu etkide sınıf ve cinsiyetin rolünün belirlenmesinin amaçlandığı bu araştırma, tarama modellerinden ilişkisel tarama modelinde gerçekleştirilmiştir. Bu modelde iki ya da daha fazla sayıdaki değişken arasındaki birlikte değişimin varlığının ve/ veya derecesinin belirlemesi amaçlanır (Karasar, 2011).

\section{Çalıs̆ma Grubu}

Araştırmanın çalışma grubu, seçkisiz örnekleme yöntemlerinden basit seçkisiz örnekleme yoluyla belirlenmiş olup katılımcılar; 2015-2016 eğitim-öğretim yılı güz döneminde Recep Tayyip Erdoğan Üniversitesi Türkçe Öğretmenliği Bölümünde 1, 2, 3 ve 4. sinıfta öğrenim gören 209 öğretmen adayından oluşmaktadır. Katılımcıların demografik özellikleri incelendiğinde; 129’u (\%61.7) k1z, 80’i (\%38.3) erkek olmakla birlikte; 72’si (\%34.4) 1. sinıfta, 57’si (\%27.3) 2. sınıfta, 41’i (\%19.6) 3. sinıfta, 39’u (\%18.7) 4. sınıfta öğrenim görmektedir.

\section{Verilerin Toplanmast}

Araştırmanın verilerinin toplanması için Recep Tayyip Erdoğan Üniversitesi Eğitim Fakültesi Dekanlığından gerekli izinler alındıktan sonra ölçeklerin uygulamalarının yapılacağı güne ilişkin ders programı incelenmiştir. Uygulama öncesinde öğrencilere araştırmayla ilgili gerekli bilgiler verilmiştir. Ölçekler 1, 2, 3 ve 4. sınıflara aynı ders saatinde uygulanmış ve bu süreç ortalama 40 dakika sürmüştür.

\section{Veri Toplama Araçları}

Araştırma verileri, Üst Bilişsel Okuma Stratejileri Ölçeği ve Yetişkin Okuma Motivasyonu Ölçeği aracılığıyla toplanmıştır. Bu ölçeklerin geçerlik ve güvenirlik çalışmalarına ilişkin sonuçlar aşağıda sunulmuştur: 
Üst bilişsel Okuma Stratejileri Ölçeği: Bu ölçme aracıyla üniversite öğrencilerinin ders metinlerini okurken kullandıkları okuduğunu anlama stratejilerinin belirlenmesi amaçlanmaktadır. Taraban, Kerr ve Rynearson (2004) tarafından geliştirilen Çöğmen ve Saracaloğlu (2010) tarafından Türkçeye uyarlanan bu ölçme aracı, "Üst Bilişsel Okuma Stratejileri Ölçeği (ÜBOS)” olarak adlandırılmıştır. Bu ölçekle üniversite öğrencilerinin ders metinlerini okuma ve çalışma sürecinde kullandıkları üstbilişsel stratejiler ölçülmektedir. Bu ölçme aracı; "her zaman kullanırım (5)", "sık sık kullanırım (4)", "bazen kullanırım (3)", "nadiren kullanırım (2)", "hiç kullanmam (1)" olmak üzere 5’li Likert tipinde hazırlanmış olup Türkçeye uyarlanması sürecinde açımlayıcı faktör analizi yapılmıştır. Bu analiz sonucunda ölçeğin analitik ve pragmatik stratejiler olmak üzere iki alt boyuttan olduğu tespit edilmiştir. Ölçeğin analitik stratejiler boyutunda 16, pragmatik stratejiler boyutunda 6 olmak üzere toplam 22 madde yer almaktadır. Birinci boyut, okuduğunu anlama sırasında bilişsel süreçleri içeren analitik stratejileri, ikinci boyut ise akademik çalışma ve başarı sürecindeki davranışları içeren pragmatik stratejileri içermektedir. Ölçeğin güvenirliği 0.84 , birinci boyutun 0.85 , ikinci boyutun ise 0.75 'tir. Her iki boyut toplam varyansın \%34.75'ini açılklamaktadır. Ölçeğin güvenirlik çalışması için Cronbach Alpha iç tutarlık katsayısı kullanılmış olup bu kat sayı ölçeğin tümü için .81; analitik stratejiler alt boyutu için .78 ve pragmatik stratejiler alt boyutu için ise .82 olarak bulunmuştur.

Üst Bilişsel Okuma Stratejileri Ölçeğinin bu araştırma için güvenirlik ve geçerlik çalışması yapılmış olup bu analizlere ilişkin sonuçlar aşağıda verilmiştir.

Doğrulayıcı faktör analizi: Üst Bilişsel Okuma Stratejileri Ölçeğinin orijinal şeklinde yer alan faktör yapılarının bu araştırma çerçevesinde doğrulanıp doğrulanmadığını tespit etmek amacıyla yapılan doğrulayıcı faktör analizi (DFA) yapılmış ve uyum iyiliği değerleri hesaplanmıştır $\left(\chi^{2}\right)$ $s d=2.08$ ( $p<.01), G F I=.84, C F I=.90, I F I=.90, R M S E A=.07$ ve $S R M R=.06)$. Bu analiz sonucunda üç faktörden oluşan ölçeğe ilişkin oluşturulan modelin uyum iyiliği indeks değerlerinin kabul edilebilir düzeyde olduğu söylenebilir (Hu ve Bentler, 1999; Jöreskog ve Sörbom, 1993; Kline, 2011; Sümer, 2000). Yapılan bu analizler neticesinde ölçeğin orijinal formundaki faktör yapılarının bu araştırma için doğrulandığı ve yeterli düzeyde geçerliğe sahip olduğu belirlenmiştir.

Güvenirlik analizi: Okuma Bilişsel Okuma Stratejileri Ölçeğinin tümünün ve alt boyutlarının güvenirliğini belirlemek için Cronbach Alpha iç tutarlık katsayısı hesaplanmıştır. Bu analiz sonucunda, 14 madde ve iki faktörden oluşan ölçeğin, Cronbach Alpha iç tutarlık katsayısı ölçeğin tümü için .74, "analitik stratejiler" boyutu için .74; "pragmatik stratejiler" boyutu için .91, hesaplanmıştır. Bu sonuçlar ölçme aracının yüksek düzeyde güvenirliğe sahip olduğunu göstermektedir.

Yetişkin Okuma Motivasyonu Ölçeği: Bu ölçme aracı üniversitelerin farklı bölümlerinde öğrenim gören öğrencilerin veya çeşitli meslek gruplarının okuma motivasyonlarının tespit edilmesi amaçlanmaktadır. Schutte ve Malouff (2007) tarafından geliştirilen "Yetişkin Okuma Motivasyonu Ölçeği (YOMO)", Yıldız, Yıldırım, Seyit, Ateş ve Çetinkaya (2013) tarafından Türkçeye uyarlanarak geçerlik ve güvenirlik analizleri yapılmıştır. Bu analizler sonucunda ölçme aracının yapı geçerliğini belirlemek için açımlayıcı ve doğrulayıcı faktör analizi yapılmıştır. $\mathrm{Bu}$ 
ölçme aracına ilişkin yapılan açımlayıcı faktör analizi sonucunda ölçeğin 21 madde ve "benlik", "yeterlilik", "tanıma", "diğer" olmak üzere 4 faktörden oluştuğu tespit edilmiştir. Ölçeğinin güvenirliğini belirlemek için Cronbach Alpha iç tutarlık katsayısı kullanılmış olup bu kat sayı ölçeğin tümü için .86, "benlik" boyutu için .82; "yeterlilik" boyutu için .60; "tanıma" boyutu için .78, "diğer" boyutu için .72 olarak hesaplanmıştır. Ölçeğe ilişkin yapılan doğrulayıcı faktör analizi sonucunda yapisal modelin uyum indekslerinin $\left(\chi^{2} / s d=2.47(p<.01), R M S E A=.07, S R M R=.05\right.$, $G F I=.87, A G F I=83, C F I=.86)$ kabul edilebilir düzeyde olduğu söylenebilir. Ölçek; "tamamen katılıyorum (5)", "katıllyorum (4)", "kısmen katılıyorum (3)", "katılmıyorum (2)", "kesinlikle katılmıyorum (1)" olmak üzere 5'li Likert tipindedir.

Yetişkin Okuma Motivasyonu Ölçeğinin bu araştırma için güvenirlik ve geçerlik çalışması yapılmış olup bu analizler aşağıda verilmiştir.

Doğrulayıcı Faktör Analizi: Yetişkin Okuma Motivasyonu Ölçeğinin orijinal şeklinde yer alan faktör yapılarının bu araştırma çerçevesinde doğrulanıp doğrulanmadığını tespit etmek amacıyla yapılan doğrulayıcı faktör analizi (DFA) yapılmış ve uyum iyiliği değerleri $\left(\chi^{2} / s d=2.12\right.$ $(p<.01), G F I=.86, C F I=.90, R M S E A=.07$ ve $S R M R=.06)$ hesaplanmıştır. Ölçeğin geçerliğine ilişkin doğrulayıcı faktör analizi (DFA) sonuçlarına göre, modelin uyum iyiliği indekslerinin değerlerinin kabul edilebilir düzeyde olduğu söylenebilir. Yapılan bu analizler sonucunda ölçeğin orijinal formundaki faktör yapılarının bu araştırma için de doğrulandığı ve yeterli düzeyde geçerliğe sahip olduğu tespit edilmiştir.

Güvenirlik analizi: Yetişkin Okuma Motivasyonu Ölçeğinin tümünün ve alt boyutlarının güvenirliğini belirlemek için Cronbach Alpha iç tutarlık katsayısı hesaplanmıştır. Bu analiz sonucunda, 19 madde ve dört faktörden oluşan ölçeğin Cronbach Alpha iç tutarlık katsayısı ölçeğin tümü için .76, "benlik" boyutu için .69; "yeterlilik" boyutu için .79; "tanıma" boyutu için .80; "diğer" boyutu için .76 olarak hesaplanmıştır. Bu sonuçlar ölçme aracının yüksek düzeyde güvenirliğe sahip olduğunu göstermektedir.

\section{Verilerin Analizi}

Verilerin analizinde SPSS 23 ve AMOS 22.0 yazılımları kullanılmış olup betimleyici istatistikler ve demografik değişkenler için frekans, yüzde, ortalama, basıklık ve çarpıklık değerleri hesaplanmıştır. Araştırmada değişkenlere ilişkin betimsel istatistiklerin hesaplanmasında ve değişkenler arasındaki ilişkilerin değerlendirilmesinde için son dönemde sosyal bilimlerde giderek artan bir öneme sahip olan yapısal eşitlik modellemesi kullanılmıştır. YEM analizi öncesinde, verilerin modeli destekleyip desteklemediğine ilişkin değerlendirmeleri yapmak amacıyla bu analizde yaygın olarak kullanılan iki aşamalı yöntem kullanılmıştır (Jöreskog ve Sörbom, 1993; Meydan ve Şeşen, 2011). Öncelikle uygulanan ölçeklerin ön incelemesi yapılmış, eksik bırakılan ve güvenilir biçimde doldurulmayan herhangi bir ölçek olmadığı tespit edilmiş ve ardından ölçekler numaralandırılma yoluyla kodlanarak sınıflandırılmıştır. Birinci aşamada modelde yer alan ölçeklerin faktör yapıları, geçerliliği ve güvenirliği tespit etmek amacıyla 
ölçeklere ilişkin DFA'lar uygulanmıştır. Her bir ölçeğe ilişin DFA sonuçları ilgili ölçeklere ilişkin bilgilerin açıklandığı bölümlerde verilmiş ve ölçeklerin elde edilen verilerle iyi uyum sergilediği orijinal formundaki faktör yapılarının bu araştırma için de doğrulandığı ortaya konulmuştur.

İkinci aşamada ise modeldeki yapılar arasındaki anlamlı ilişkiler değerlendirilmiştir. YEM analizine başlanılmadan önce bu analize ilişkin varsayımlar kontrol edilmiştir. Bu analiz için gerekli olan örneklem büyüklüğü, çok değişkenli normallik ve çoklu bağlantılılık varsayımları test edilmiştir. YEM için önerilen örneklem büyüklügünün 100-150 olması yeterlidir (Kline, 2011). Çok değişkenli normallik varsayımının karşılanması için gerekli ön koşul olan tek değişkenli normallik için her değişkene ait çarpıklık (skewness) ve basıklık (kurtosis) değerleri hesaplanmıştır (Kline, 2011). Çoklu değişkenli normallik varsayımının incelenmesinde Mardia’nın normalleştirilmiş çok değişkenli basıklık katsayısı hesaplanmıştır (Raykov ve Marcoulides, 2008). Veri setine ilişkin varsayımların sağlanmasının ardından modelin bir bütün olarak veri setiyle uyumu incelenmiştir. YEM'de parametrelerin tahminine ilişkin analizlerde maksimum olabilirlik (Maximum Likehood) tekniği tercih edilmiștir. Analiz sonucunda modelin uyumuna ilişkin değerlendirmelerde ise $\chi^{2} / d f$, CFI, GFI, TLI, NFI, IFI, RMSEA ve SRMR uyum indeksleri kullanılmıştır. Analizler sonucunda uyum indekslerinin modele uyum düzeyleri ve yorumları Tablo 1'de verilmiştir (Hu ve Bentler, 1999; Klem, 2000; Kline, 2011).

\section{Tablo 1}

Yapısal Eşitlik Modelleri Uyum İndeksleri

\begin{tabular}{ccc}
\hline Uyum indeksleri & İyi uyum & Kabul edilebilir Uyum \\
\hline$\chi^{2} / s d$ & $0 \leq \chi^{2} / \mathrm{sd} 0 \leq 2$ & $2<\chi^{2} / \mathrm{sd} \leq 5$ \\
$R M S E A$ & $0 \leq \mathrm{RMSEA} \leq .05$ & $.05<\mathrm{RMSEA} \leq .08$ \\
$S R M R$ & $0 \leq \mathrm{SRMR} \leq .05$ & $.05 \leq \mathrm{SRMR} \leq .10$ \\
$I F I$ & $0.95 \leq \mathrm{IFI}<1.00$ & $0.90 \leq<\mathrm{IFI}<0.95$ \\
$T L I$ & $0.95 \leq \mathrm{TLI}<1.00$ & $0.90 \leq \mathrm{TLI}<0.95$ \\
$C F I$ & $0.95 \leq \mathrm{CFI}<1.00$ & $0.90 \leq \mathrm{CFI}<0.95$ \\
GFI & $0.95 \leq \mathrm{GFI}<1.00$ & $0.90 \leq \mathrm{GFI}<0.95$ \\
NFI & $0.95 \leq \mathrm{NFI}<1.00$ & $0.90 \leq \mathrm{NFI}<0.95$ \\
\hline
\end{tabular}

\section{Bulgular}

Araştırma sonucunda elde edilen bulgular iki bölümde sunulmuştur: Birinci bölümde betimleyici istatistiklere ikinci bölümde ise yapısal eşitlik modellemesinde yer alan değişkenlere ve bu değişkenler arasındaki ilişkilere ait tahminlere, değişkenlerin açıklanma oranlarına ve model uyumlarına ilişkin bulgulara yer verilmiştir.

\section{Model Değişkenlerine İlişkin Betimleyici İstatistikler}

Araştırma modelinde yer alan değişkenlere (AS, PS, BN, YT, TN, DG) ilişkin betimsel istatistikler Tablo 2'de sunulmuştur. 
Tablo 2

Ölçüm Maddelerine İlişkin Betimleyici İstatistikler

\begin{tabular}{|c|c|c|c|c|c|c|c|}
\hline \multicolumn{8}{|c|}{ Faktörler } \\
\hline & & AS & PS & $\mathrm{BN}$ & YT & $\mathrm{TN}$ & $\overline{D G}$ \\
\hline \multirow{4}{*}{ 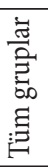 } & $\mathrm{M}$ & 54.55 & 22.40 & 28.66 & 13.12 & 9.20 & 13.62 \\
\hline & SS & 8.09 & 5.36 & 6.15 & 2.73 & 3.05 & 3.27 \\
\hline & SK & -.66 & -.59 & -.72 & -.01 & .17 & -.27 \\
\hline & K & 1.12 & .09 & .41 & .16 & -.56 & .13 \\
\hline \multirow{4}{*}{$\begin{array}{l}\text { 亗 } \\
\text { 其 } \\
\text { - }\end{array}$} & $\mathrm{M}$ & 54.56 & 22.48 & 28.35 & 13.23 & 8.68 & 13.43 \\
\hline & SS & 8.54 & 5.70 & 6.55 & 2.90 & 3.27 & 3.77 \\
\hline & SK & $-1,31$ &,- 63 & $-1,06$ & -.23 & .14 & -.55 \\
\hline & K & 2.82 & -.04 & 1.19 & .46 & -.70 & .21 \\
\hline \multirow{4}{*}{$\begin{array}{l}\text { 嵌 } \\
\text { ¿ } \\
\text { ¿ }\end{array}$} & $\mathrm{M}$ & 55.76 & 22.87 & 29.46 & 13.24 & 9.95 & 13.82 \\
\hline & SS & 8.34 & 5.45 & 5.62 & 2.54 & 3.01 & 2.81 \\
\hline & SK & -.40 & -.12 & -.23 & .37 &,- 03 & .09 \\
\hline & $\mathrm{K}$ & -.74 & -.76 & -.36 & -.36 &,- 75 & -.08 \\
\hline \multirow{4}{*}{$\begin{array}{l}\text { 崩 } \\
\text { 出 } \\
\dot{m}\end{array}$} & $\mathrm{M}$ & 52.97 & 22.09 & 29.40 & 13.10 & 9.49 & 14.21 \\
\hline & SS & 7.33 & 4.54 & 5.51 & 2.44 & 3.07 & 3.01 \\
\hline & SK & -.93 & -.51 & -.90 & -.12 &, 44 & -.35 \\
\hline & $\mathrm{K}$ & .42 & .56 & .22 & -.22 &,- 77 & -.84 \\
\hline \multirow{4}{*}{$\begin{array}{l}\text { 荘 } \\
\text { क } \\
\forall\end{array}$} & $\mathrm{M}$ & 54.41 & 21.86 & 27.30 & 12.74 & 8.77 & 13,07 \\
\hline & SS & 7.65 & 5.49 & 6.69 & 3.01 & 2.46 & 3,16 \\
\hline & SK &,- 02 & -.89 & -.22 & .15 & .36 & .55 \\
\hline & $\mathrm{K}$ & .03 & .89 & -.79 & .01 & .49 & -.08 \\
\hline \multirow{4}{*}{ 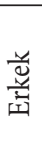 } & $\mathrm{M}$ & 51.83 & 19.86 & 26.97 & 12.92 & 8.63 & 12.65 \\
\hline & SS & 8.91 & 5.54 & 5.88 & 2.62 & 3.02 & 2.72 \\
\hline & SK & -.56 & -.38 & -.50 & .09 & .55 & -.24 \\
\hline & $\mathrm{K}$ & .85 & -.07 & .07 & .21 & -.25 & .92 \\
\hline \multirow{4}{*}{ 吾 } & $\mathrm{M}$ & 56.23 & 23.97 & 29.71 & 13.24 & 9.55 & 14.23 \\
\hline & SS & 7.07 & 4.60 & 6.10 & 2.80 & 3.03 & 3.44 \\
\hline & SK & -.49 & -.58 & -.95 & -.07 & -.05 & -.50 \\
\hline & $\mathrm{K}$ & .74 & -.04 & 1.00 & .15 & -.50 & .12 \\
\hline
\end{tabular}

Tablo 2'ye göre araştırma modelinde yer alan tüm değişkenlere (AS, PS, BN, YT, TN, DG) ilişkin aritmetik ortalamalar ilgili puan aralığının orta noktasının üzerinde olup bu değerler 8.63 ile 56.23 arasında değişmektedir. Bu durum katılımcıların ölçülen özelliklere ilişkin ortalamalarının olumlu olduğunu göstermektedir. Standart sapma değerleri incelendiğinde ise bu değerlerin ortalamalara yakın sayılabilecek değerler olduğu söylenebilir. Verilere ilişkin tek değişkenli normalliğin varsayılabilmesi değişkenlere ait çarpıklık (skewness) ve basıklık (kurtosis) değerlerinin sırasıyla |3.0|'ten ve |10.0|'dan büyük olmaması gereklidir (Kline, 2011). Buna göre değişkenlere ilişkin çarpıklık değerlerinin - .01 ile - 1.31; basıklık değerlerinin ise - .84 ile 2.82 aralığında değiştiği gözlenmiştir. Bu bulgular, verilere ilişkin tek değişkenli normalliğin sağlandığını göstermektedir. Çoklu değişkenli normallik varsayımının sağlanıp sağlanmadığının belirlenmesinde ise Mardia’nın normalleştirilmiş çok değişkenli basıklık katsayısı hesaplanmış ve araştırmada yer alan tüm gruplar için (tüm örneklem, 1. sınıf, 2. sınıf, 3. sınıf, 4. sınıf, kadın, erkek) bu değer sirasıyla 7.65, 10.54, 2.03, 3.49, 2.80, 3.24, 6.96 olarak 
bulunmuştur. Bu dağılıma ilişkin varsayımın sağlanabilmesi için çok değiş̧kenli normallik için kritik değer; Raykov ve Marcoulides (2008)'in önerdiği $p(p+2)$ ( $p$ : gözlenen değişken sayısı) denkleme göre hesaplanmış olup bu değer de 48 olarak bulunmuştur. Raykov ve Marcoulides (2008)'e göre çok değişkenli normallik için denklemden elde edilen bu değerin basıklık katsayısından büyük olması gereklidir. Denklemden elde edilen değerin (48) çok değişkenli basıklık katsayılarından $(7.65,10.54,2.03,3.49,2.80,3.24,6.96)$ büyük olması sebebiyle çok değişkenli normallik varsayımının sağlandığı görülmektedir.

\section{Ölçme Modeline İlişkin Bulgular}

Araştırmanın amacı doğrultusunda Türkçe öğretmeni adaylarının üst bilişsel okuma stratejilerinin, okuma motivasyonlarını yordama düzeyine ilişkin modellerin (tüm örneklem, sınıf ve cinsiyet) testine dair sonuçlar Şekil 4’te (a, b, c, d, e, f) sunulmuştur.

Not: Üst Bilişsel Okuma Stratejileri Ölçeği (PS: Pragmatik Stratejiler, AS: Analitik Stratejiler), Okuma Motivasyonu Ölçeği (BN: Benlik, YT: Yeterlilik, TN: Tanıma, DG: Diğer).

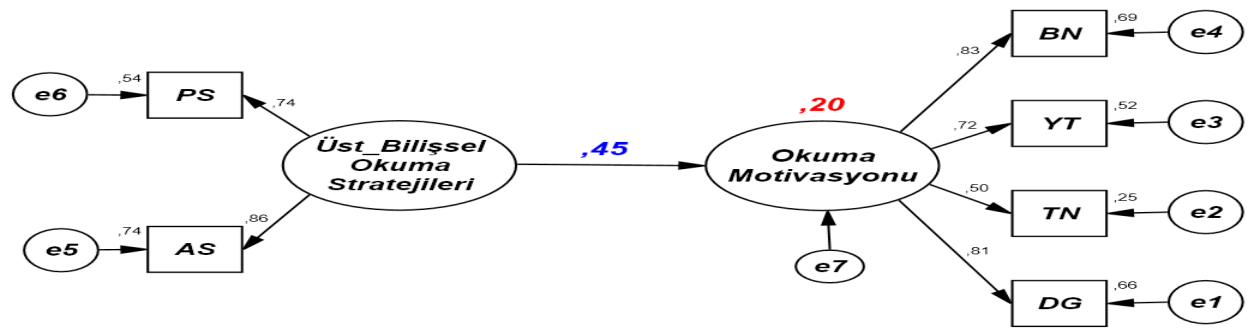

Şekil 2a. Tüm örneklem

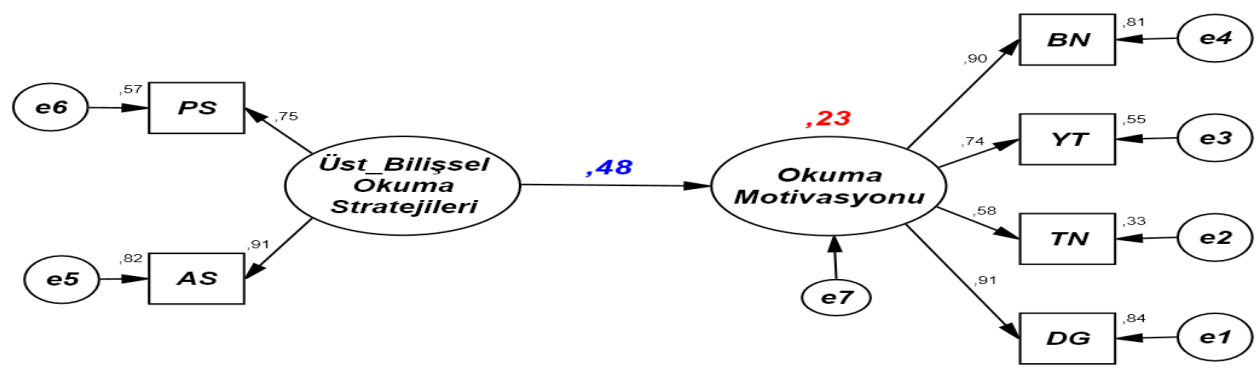

Şekil 2b. 1. sınıf 


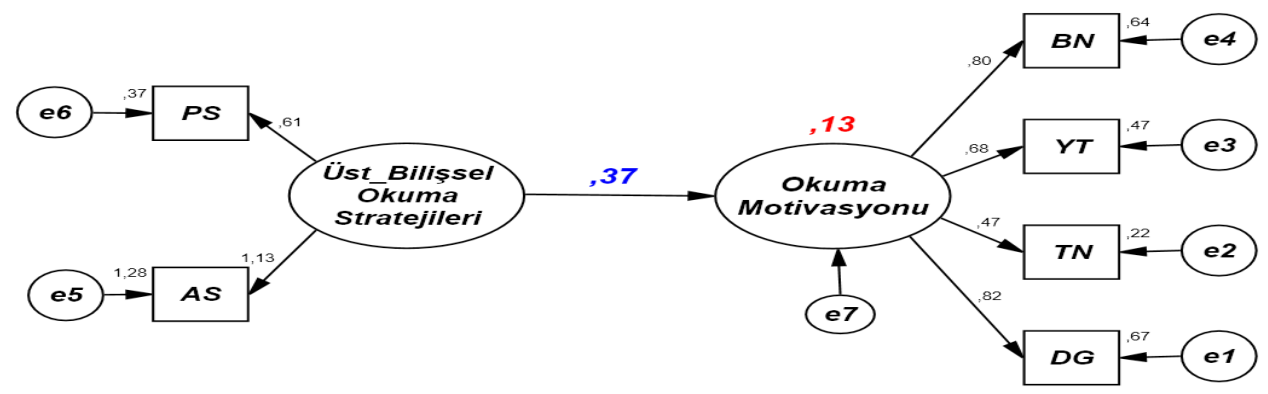

Şekil 2c. 2. sınıf

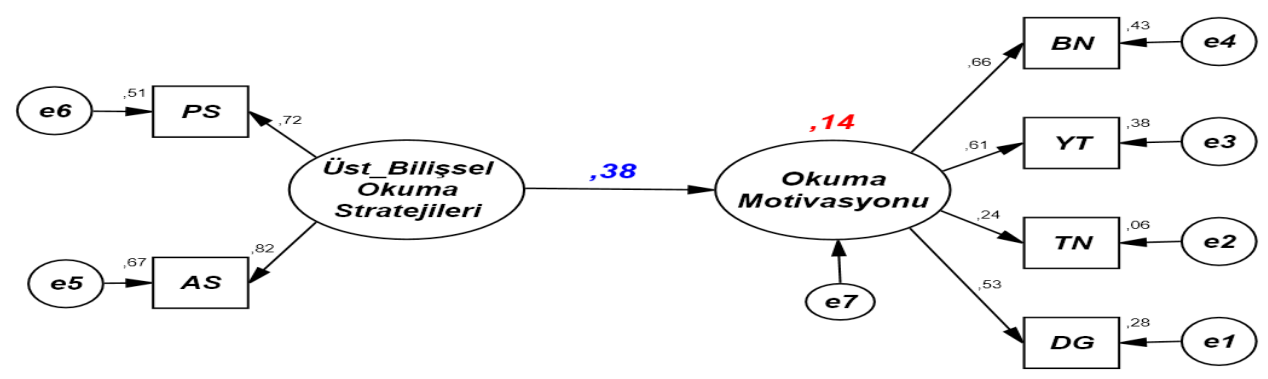

Şekil 2d. 3. sınıf

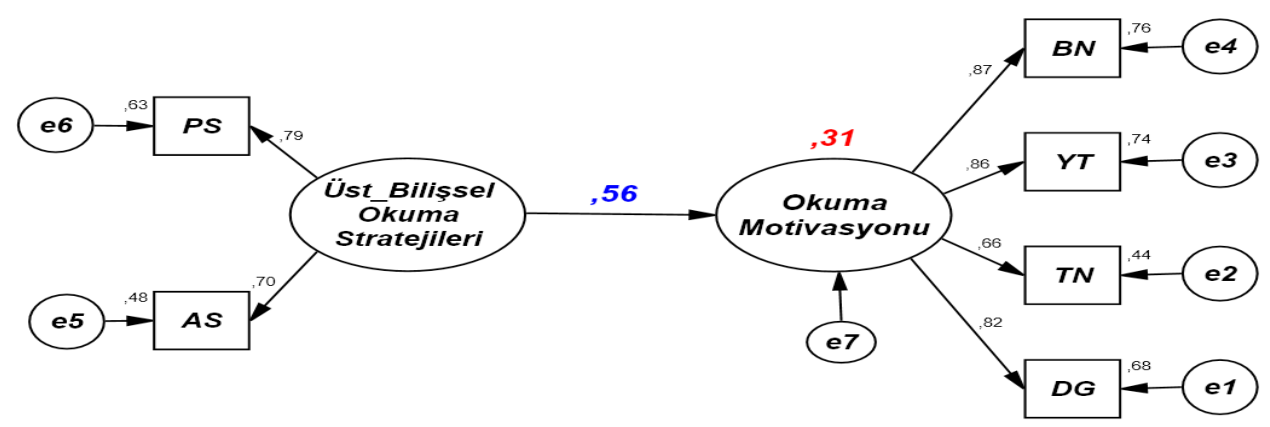

Şekil 2e. 4. sınıf 


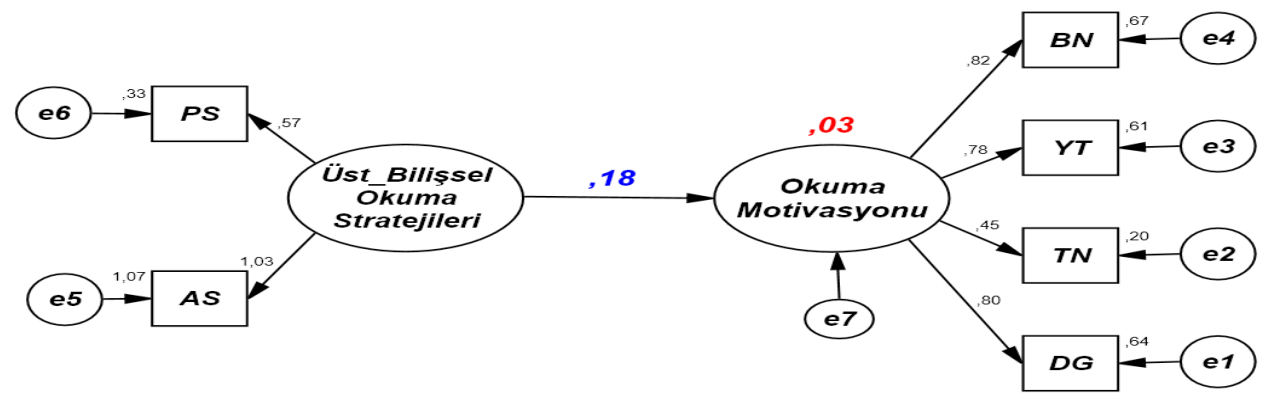

Şekil 2f. Kadın öğretmen adayları

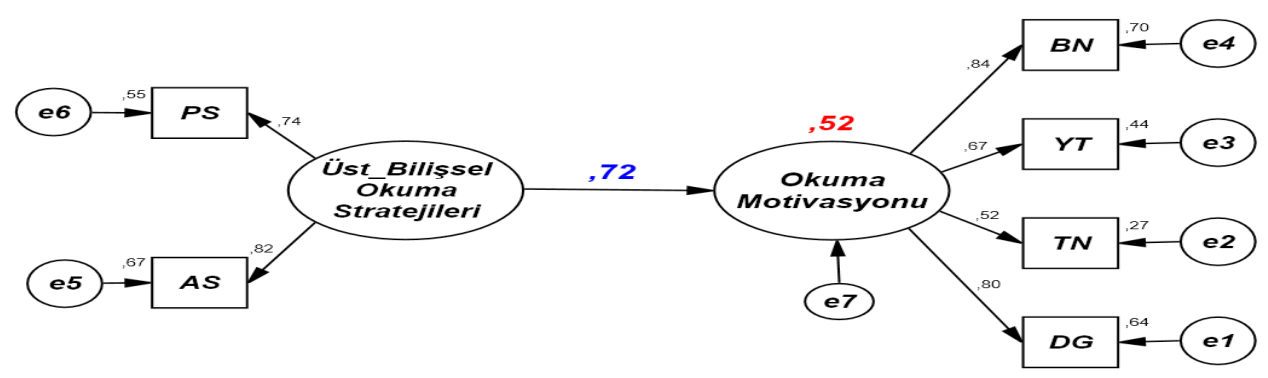

Şekil 2g. Erkek öğretmen adayları

Üst bilişsel okuma stratejilerinin, okuma motivasyonu üzerindeki etkisini belirlemeye yönelik oluşturulan yapısal eşitlik modellemesi sonucunda; tüm örnekleme ilişkin kurulan modelde $\left(\chi^{2} / d f=1.33 ; G F I=.98 ; C F I=.99 ; R M S E A=.40 ; S R M R=.03\right)$, 1. sinıflara ilişkin kurulan modelde $\left(\chi^{2} / d f=.89 ; G F I=.97 ; C F I=1.00 ; R M S E A=.00 ; S R M R=.02\right)$, 2. sinıflara ilişkin modelde $\left(\chi^{2} / d f=.66 ; G F I=.97 ; C F I=1.00 ; R M S E A=.00 ; S R M R=.05\right), 3$. sinıflara ilişkin modelde $\left(\chi^{2} / d f=2.03\right.$; $G F I=.94 ; C F I=.99 ; R M S E A=.02 ; S R M R=.09)$, 4. sinıflara ilişkin modelde $\left(\chi^{2} / d f=.22 ; G F I=.99\right.$; $C F I=1.00 ; R M S E A=.00 ; S R M R=.02)$, erkek öğretmen adaylarına ilişkin modelde $\left(\chi^{2} / d f=.81\right.$; $G F I=.97 ; C F I=1.00 ; R M S E A=.00 ; S R M R=.03)$ ve kadın öğretmen adaylarına ilişkin modelde $\left(\chi^{2} /\right.$ $d f=1.27 ; G F I=.97 ; C F I=.99 ; R M S E A=.04 ; S R M R=.03)$ uyum iyiliği indekslerinin kabul edilebilir düzeyde olduğu söylenebilir. Yapısal modelin testi sonucunda üst bilişsel okuma stratejileri gizil değişkeninin faktör yüklerinin tüm örnekleme ilişkin model için .74 ile .86, 1. sınıflara ilişkin modelde .75 ile .82 , 2. sınıflara ilişkin modelde .72 ile .82 , 3. sınıflara ilişkin modelde .61 ile 1.13, 4. sınıflara ilişkin modelde ise .79 ile .70 , kadın öğretmen adaylarına ilişkin modelde .57 ile 1.03, erkek öğretmen adaylarına ilişkin modelde .74 ile .82, arasında değişmektedir. Okuma motivasyonu gizil değişkeninin faktör yüklerinin tüm örnekleme ilişkin model için .50 ile .83 , 1. sınıflara ilişkin modelde .58 ile .90 , 2. sınıflara ilişkin modelde .24 ile .66 , 3. sınıflara ilişkin 
modelde .47 ile .82 , 4 . sınıflara ilişkin modelde ise .66 ile .87 , kadın öğretmen adaylarına ilişkin modelde .45 ile .82 , erkek öğretmen adaylarına ilişkin modelde .54 ile .82, arasında değişmektedir. Bu bulgulara göre tüm modellerde

Tablo 3

Üst Bilişsel Okuma Stratejilerinin Okuma Motivasyonu Üzerindeki Etkisine İlişkin Standardize Edilmiş Regresyon A ̈̆ırlığı Sonuçları

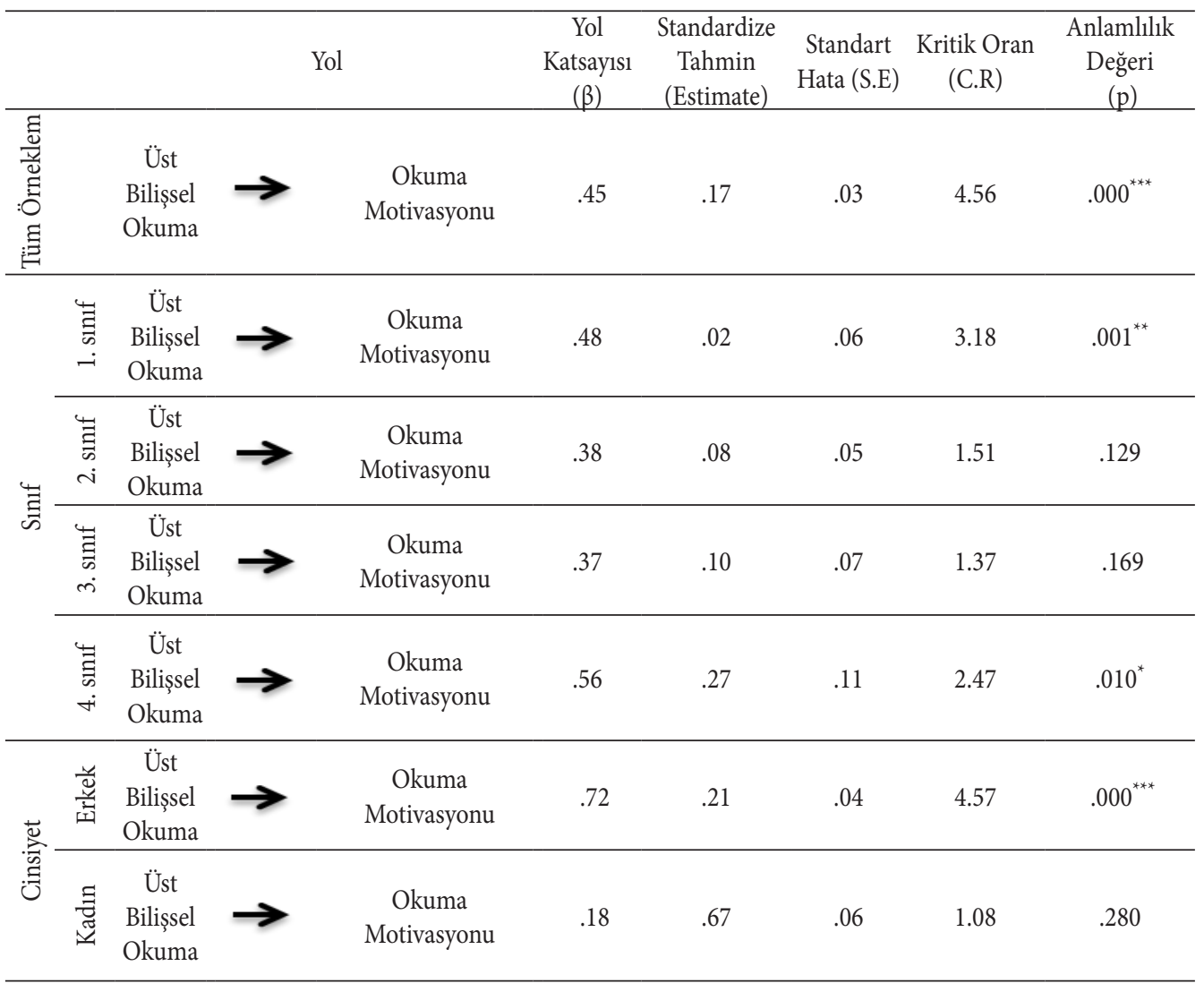

Tablo 3’e göre modeller çerçevesinde değerlendirilen yedi hipotezden dördü istatistiksel olarak veri tarafından desteklenmiş diğer üç hipotez ise reddedilmiştir. Tüm örnekleme ilişkin modelde üst bilişsel okuma stratejilerinin, okuma motivasyonunu pozitif yönde ve manidar düzeyde yordadığı görülmüş $(\beta=.45, \mathrm{p}<.01)$ ve $\mathrm{H}_{1}$ hipotezi kabul edilmiştir. 1. sinıflara ilişkin modelde üst bilişsel okuma stratejilerinin, okuma motivasyonunu pozitif yönde ve manidar düzeyde yordadığı görülmüş $(\beta=.48, \mathrm{p}<.01)$ ve $\mathrm{H}_{2}$ hipotezi kabul edilmiştir. 2. sinıflara ilişkin modelde üst bilişsel okuma stratejilerinin, okuma motivasyonunu manidar düzeyde yordamadı̆̆ 1 görülmüş $(\beta=.38, \mathrm{p}>.05)$ ve $\mathrm{H}_{3}$ hipotezi reddedilmiştir. 3. sınıflara ilişkin modelde üst bilişsel okuma stratejilerinin, okuma motivasyonunu manidar düzeyde yordamadığı görülmüş ( $\beta=.37$, 
p >.05) ve $\mathrm{H}_{4}$ hipotezi reddedilmiştir. 4. sınıflara ilişkin modelde üst bilişsel okuma stratejilerinin, okuma motivasyonunu pozitif yönde ve manidar düzeyde yordadığı görülmüş $(\beta=.56, \mathrm{p}<.01)$ ve $\mathrm{H}_{5}$ hipotezi kabul edilmiştir. Erkek öğretmen adaylarına ilişkin modelde üst bilişsel okuma stratejilerinin, okuma motivasyonunu pozitif yönde ve manidar düzeyde yordadı̆̆ı görülmüş $(\beta=.72, \mathrm{p}<.01)$ ve $\mathrm{H}_{6}$ hipotezi kabul edilmiştir. Kadın öğretmen adaylarına ilişkin modelde üst bilişsel okuma stratejilerinin, okuma motivasyonunu manidar düzeyde yordamadığ görülmüş $(\beta=.18, \mathrm{p}>.05)$ görülmüş ve $\mathrm{H}_{6}$ hipotezi reddedilmiştir.

\section{Tablo 4}

Standartlaştırılmış Doğrudan, Dolaylı ve Toplam Etki Büyüklükleri

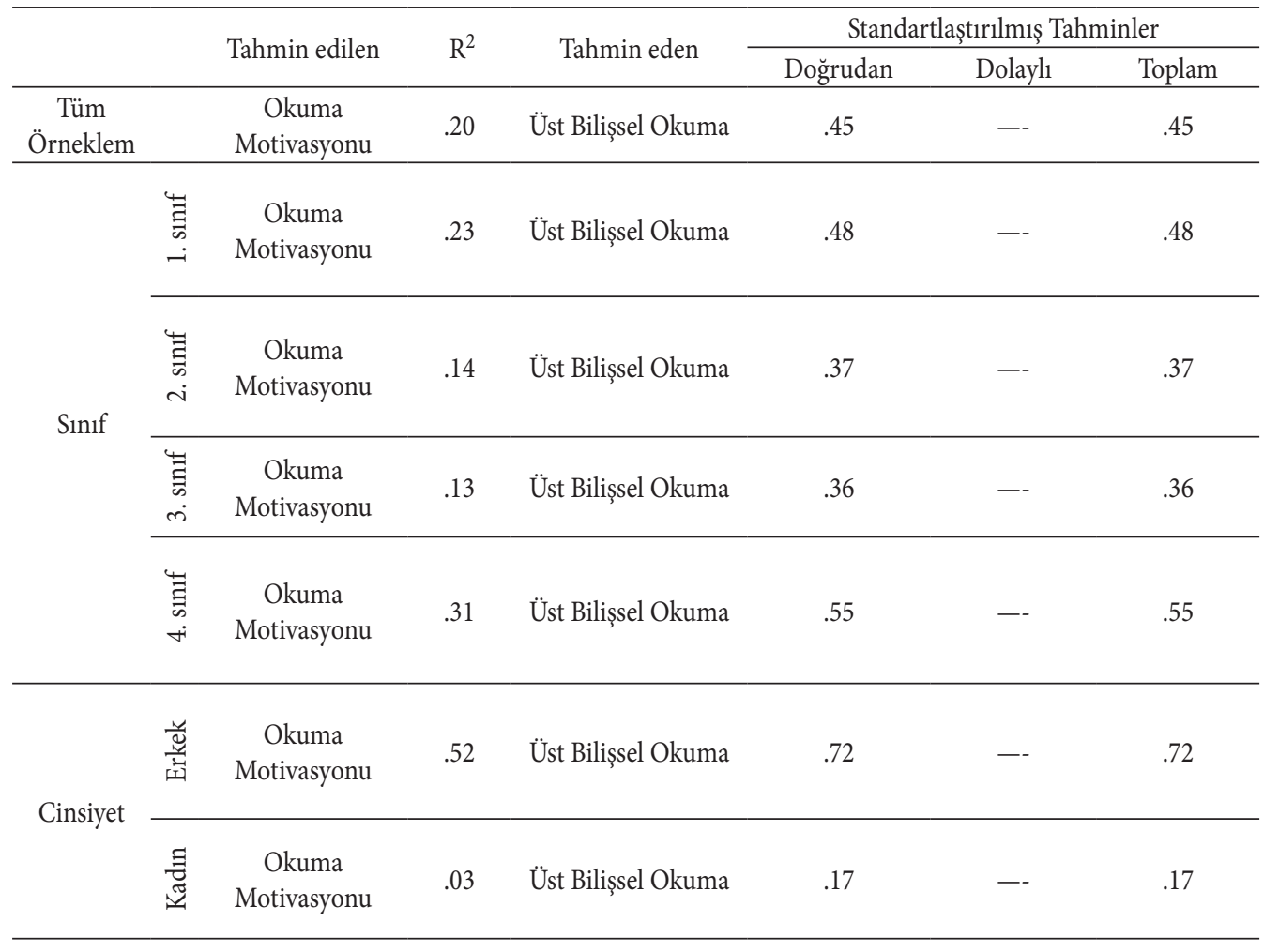

Tablo 4'e göre tüm örnekleme ilişkin modelde üst bilişsel okuma stratejilerinin, okuma motivasyonu üzerinde toplam ve doğrudan .45 ile yüksek bir etki oluşturduğu ve okuma motivasyonuna ilişkin varyansın \%20'lik kısmını açıkladığı görülmüştür. 1. sınıflara ilişkin modelde üst bilişsel okuma stratejilerinin, okuma motivasyonu üzerinde toplam ve doğrudan .48 ile yüksek bir etki oluşturduğu ve okuma motivasyonuna ilişkin varyansın \%23'lük kısmını açıkladığı görülmüştür. 2. sınıflara ilişkin modelde üst bilişsel okuma stratejileri, okuma motivasyonunu manidar düzeyde yordamadığından ( $\mathrm{p}>.05)$ bu modelde toplam ve doğrudan $\left(d_{\text {doğrudan }}=.37, d_{\text {toplam }}=.37\right)$ etki anlamsızdır. 3. sınıflara ilişkin modelde üst bilişsel okuma stratejileri, 
okuma motivasyonunu manidar düzeyde yordamadığından ( $\mathrm{p}>.05)$ bu modelde toplam ve doğrudan $\left(d_{\text {doğrudan }}=.36, d_{\text {toplam }}=.36\right)$ etki anlamsızdır. 4. sinıflara ilişkin modelde üst bilişsel okuma stratejilerinin, okuma motivasyonu üzerinde toplam ve doğrudan .55 ile yüksek bir etki oluşturduğu ve okuma motivasyonuna ilişkin varyansın \%31'lik kısmını açıkladığı görülmüştür. Erkek öğretmen adaylarına ilişkin modelde okuma stratejilerinin, okuma motivasyonu üzerinde toplam ve doğrudan .72 ile yüksek bir etki oluşturduğu ve okuma motivasyonuna ilişkin varyansın $\% 52$ 'lik kısmını açıkladığı görülmüştür. Kadın öğretmen adaylarına ilişkin modelde üst bilişsel okuma stratejilerinin, okuma motivasyonunu manidar düzeyde yordamadığından ( $>$ >05) bu modelde toplam ve doğrudan $\left(d_{\text {doğrudan }}=.03, d_{\text {toplam }}=.03\right.$ ) etki anlamsızdır.

\section{Sonuç ve Tartışma}

Üst bilişsel okuma stratejilerinin, okuma motivasyonu üzerindeki etkisi ve bu etkide sınıf düzeyi ve cinsiyetin rolünün incelendiği bu araştırmada, alan yazına dayalı olarak oluşturulan hipotezler yapısal eşitlik modellemesiyle incelenmiştir. Araştırma sonucunda hipotez modelleri test edilmiş ve tüm modellerin geçerli olduğu sonucuna ulaşılmıştır. Araştırma kapsamında oluşturulan yedi hipotezden dördü veri tarafından desteklenmiş, diğer üç hipotez ise reddedilmiştir. Tüm örnekleme ilişkin modelde üst bilişsel okuma stratejilerinin, okuma motivasyonu üzerinde yüksek düzeyde pozitif bir etki oluşturduğu ve okuma motivasyonuna ilişkin varyansın \%20’sini açılladığı görülmüştür. Araştırma sonuçları sınıf düzeyine ilişkin oluşturulan modeller açısından değerlendirildiğinde üst bilişsel okuma stratejilerinin; okuma motivasyonuna ilişkin varyansin 1. sinıfta \%23’ünü, 2. sinıfta \%14'ünü, 3. sinıfta \%13’ünü, 4. sınıfta \%31'ini açıklamaktadır. Bu bulgulardan hareketle üst bilişsel okuma stratejilerinin, okuma motivasyonuna ilişkin açıklama oranının sınıf düzeyine göre farklılaştı̆̆ı, 4. sınıfta ise en yüksek düzeye ulaştğ̆ söylenebilir. Cinsiyete ilişkin oluşturulan modellerde ise üst bilişsel okuma stratejilerinin, okuma motivasyonuna ilişkin varyansın erkek öğretmen adaylarında \%52'sini, kadın öğretmen adaylarında ise \%3'ünü açıkladığı ve bu modellerde erkek öğretmen adaylarındaki açıklama oranın, kadın öğretmen adaylarına göre çok yüksek olduğu tespit edilmiştir. Bu sonuçlardan gerek tüm modellerde, üst bilişsel okuma stratejileriyle okuma motivasyonunun ilişkili olduğu görülmüş ve tüm modeller doğrulanmıştır. Benzer şekilde Meniado (2016)'nun araştırmasında da üst bilişsel okuma stratejileri ve okuma motivasyonu arasında pozitif bir ilişki olduğu tespit edilmiştir. Memiş ve Bozkurt (2013)'un araştırmasında ise üst bilişsel okuduğunu anlama, okuma motivasyonuna ilişkin toplam varyansın \%33'ünü açıklamakla birlikte iç-dış motivasyon arasında orta derecede anlamlı bir ilişki vardır. İflazoğlu Saban ve Saban (2008)'ın araştırmasında sınıf öğretmeni adaylarının bilişsel farkındalıkları ve güdülenmeleri arasında pozitif yönlü anlamlı bir ilişki olduğu, bilişsel farkındalıklarının artışına bağlı olarak güdülenmelerinin de arttığı tespit edilmiştir. Jamshidi ve Moghaddam (2013)'in araştırmasında ise okuduğunu anlama stratejileri ve okuma motivasyonu arasındaki ilişkinin varlığı, Pierce (2003)'nin araştırmasında üst bilişin, öz-yeterlik üzerinden motivasyonu etkilediği ortaya konulmuştur. Kolic-Vehovec ve Bajsanski (2006)'nin araştırmasında ise üstbilişsel takip ile okuma-anlama becerileri arasında anlamlı ve güçlü bir ilişsi olduğu bulunmuştur. Van 
Kraayenoord ve Schneider (1999), motivasyon faktörlerinin de dahil edildiği araştırmasında üstbilişsel strateji bilgisinin, okumanın en iyi yordayıcılarından biri olduğunu tespit etmiştir. Okuma becerilerinin gelişmesinde olumlu bir etki oluşturan üst bilişsel okuma stratejilerinin (Tice, 1991), okuma stratejileri (Tavakoli, 2014; Yüksel ve Yüksel, 2012) ve okuduğunu anlama ile arasındaki ilişki (Ahmadi, İsmail ve Abdullah, 2013; Çakıroğlu, 2007, Çetinkaya ve Erktin, 2002; İsmail ve Tawalbeh, 2015; İlustre, 2011; Memis ve Bozkurt, 2013; Şen, 2009) bu araştırmadan elde edilen üst bilişsel stratejilerle okuma arasındaki pozitif ilişkiye dair sonucu desteklemektedir. Bununla birlikte okuduğunu anlama ve okuma performansı ile üst bilişsel okuma stratejileri arasında pozitif bir ilişki olmadığını ortaya koyan çeşitli çalışmalar da mevcuttur (Alsamadani, 2009; Korotaeva, 2012; Mehrdad, Ahghar ve Ahghar, 2012; Pammu, Amir ve Maasum, 2014; Pei, 2014). Alan yazındaki çalışmalar bütün olarak değerlendirildiğinde ise genel olarak üst bilişsel okuma stratejilerinin, okuma üzerinde pozitif bir etki oluşturduğu söylenebilir. Bu sonuçlardan hareketle okuma üstbilişsel stratejilerinin kullanımının okuma motivasyonun önemli bir yordayıcısı olduğu, üstbilişsel stratejilerin bilinmesi ve beraberinde geliştirilmesinin okuma motivasyonu açısından bir gereklilik olduğu söylenebilir.

Araştırma sonucunda Türkçe öğretmeni adaylarının üst bilişsel okuma strateji kullanımları ile okuma motivasyonu arasındaki ilişkinin pozitif yönde oluşundan hareketle öğretmen adaylarının üst bilişsel okuma strateji kullanımları arttıkça okuma motivasyonlarının da arttığı söylenebilir. Benzer çalışmalarda ise okuma motivasyonları arttıkça okuma yeterlilikleri, okuduğunu anlama düzeylerinde artmaktadır (Ahmadi vd, 2013; Jafari ve Shokrpour, 2012). Üst bilişsel okuma becerilerine sahip bireyler, okuma sürecindeki bilişsel işlemlerini değerlendirmektedirler. $\mathrm{Bu}$ süreç kendi kontrollerinde olduğu için okuma motivasyonları da arttırmaktadır (Flavell, 1979). Okuma motivasyonun arttırılması için üst bilişsel becerilerin aktif kullanımının, motivasyon ve diğer duyuşsal değişkenlerle olan ilişkilerini desteklemektedir (Yıldızlı ve Saban, 2015). Benzer şekilde alan yazındaki araştırmalarda bilişsel farkındalık becerilerinin, motivasyonu arttırdığını ortaya koymaktadır (Costa ve Lowery, 1989; Hall ve Myers, 1998; Manning ve Glasner, 1996). Cantrell vd., (2016) tarafından yapılan araştırmada okuma stratejilerinin kullanımının, okuma motivasyonu üzerinde etkili olduğu ortaya konulmuştur.

Okuma, bilişsel bir süreç olmasının yanı sıra güdüsel süreçlerin de eş zamanlı olarak hareket ettiği karmaşık bir eylemdir (Guthrie ve Wigfield, 2005). Bu çerçevede bilişsel süreçlerin ve bunları destekleyen üst bilişsel süreçlerinde bilinmesi, okuduğunu anlamaya (Başaran, 2013; Weir, 1998) ve okuma motivasyonun artışına katkı sağlayarak okuma sıklığını arttırmaktadır (Butler, vd., 2011; Çakıroğlu, 2007; Çakıroğlu ve Ataman, 2008; Çiçekçioğlu, 2003; Eker, 2014). Bu durumda da üst bilişsel becerilerin kullanımını daha aktif hale getirerek bilgiye erişimi ve bilginin aktif bir şekilde kullanımına olanak sağlamaktadır (Ciardiello, 1998; Çalışkan ve Sünbül, 2011). Schraw (2002)'a göre motivasyonu etkileyen stratejilerin kullanımı öğrenmeye yönlendirmekte ve beraberinde motivasyonun artışını sağlayarak etkili stratejileri öğrenmek için yeni hedefler belirlemelerini sağlamaktadır. Nitekim araştırmalar da okuma motivasyonunun; okuma miktarı, ve okuma tutum, hız ve alışkanlığıyla arasındaki pozitif bir ilişkiyi desteklemektedir (Baki, 2018; Karahan, 2016; McGeown, Duncan, Griffiths ve Stothard, 2015; Meniado, 2016;). Bu sonuçlar 
Edizer-Çetinkaya (2015)'nın araştırmasında Türkçe öğretmen adaylarının üst bilişsel okuma stratejilerini kullanım düzeyleri ile okuma tutumları arasında pozitif ilişkiye, Wright ve Jacobs (2003)'n araştırmasında bilişüstü stratejilerin kullanımının okuma zorluklarını azalttığı ve okuma performansını geliştirdiğine ilişkin sonuçlarla örtüşmektedir. Benzer şekilde Muhtar (2006)'ın araştırmasında da üstbilişsel strateji eğitiminin, okuma becerisine ilişkin başarıyı arttırdığ belirlenmiştir. Gelen (2003)'in araştırmasında ise bilişsel farkındalık stratejilerinin kullanımının, Türkçe dersinde okuduğunu anlama başarısını, derse ilişkin tutumu olumlu yönde geliştirdiği ve beraberinde bilişsel farkındalık becerileri ve okuduğunu anlama başarıları açısından kalıcllığ artırdığı belirlenmiştir. Temizkan (2008) da bilişsel okuma stratejilerinin, Türkçe derslerinde bilgiye dayalı metinlerde okuduğunu anlama üzerinde etkili olduğunu tespit etmiştir. Üst bilişsel stratejilerin kullanımının bu etkisinin yanı sıra Temizkan (2007)'ın bir diğer araştırmasında okuma stratejilerinin de okuduğunu anlama üzerinde deney grubu lehine manidar düzeyde farklılık gösterdiği ortaya konulmuştur. Çakıroğlu ve Ataman (2008)'n araştırmasında üstbiliş stratejilerin kullanımının; okuma ve anlama etkinliklerinde, amaç belirleme, plan yapma, kendini ve sureci kontrol etme, kendini değerlendirme gibi beceriler kazandırılmasına katkı sağladığı ve okuduğunu anlama düzeyini arttırdığı tespit edilmiştir. Çünkü üst bilişsel okuma stratejileri, okuma sürecinde bilişsel süreçlerin farkında olma yani bilgiyi ayırt etmeyi ve okuma sürecinde stratejik davranmayı bilmeyi gerekli kilmaktadır (Al-Sobhani, 2013; Caron, 1997).

Üst billişsel okuma stratejilerinin kullanımı pek çok değişkenle ilişkili olup öğrenim sürecinde aktif bir rol üstlenmektedir (Hall ve Myers, 1998). Yapılan araştırmalar öğretmen adaylarının üst bilişsel farkındalık düzeyleri ile problem çözme becerileri arasındaki ilişkinin (Kışkır, 2011) yanı sıra eleştirel okuma eğitiminin, üst bilişsel okuma stratejileri üzerinde etkili olduğunu desteklemektedir (Karabay, 2015). Karasakaloğlu vd., (2012), Türkçe öğretmen adaylarının üst bilişsel okuma stratejilerini başarılı biçimde kullandıkları, üst bilişsel ve motivasyonel becerilere sahip olduklarını belirtmektedir. Çöğmen (2008)'in araştırmasında ise Türkçe öğretmeni adaylarının üst bilişsel okuma stratejilerinden, analitik okuma stratejilerini kullanma durumları diğer bölümlerdeki öğretmen adaylarına göre manidar düzeyde farklılaşmaktadır. Aybek ve Aslan (2016)'in araştırmasında bu durumun sebepleri arasında sözel alanlarda öğrenim gören öğretmen adaylarının üsbilişsel okuma stratejilerini diğer alanlarda öğrenim gören öğretmen adaylarından daha iyi kullandıkları belirlenmiştir. Topuzkanamış ve Maltepe (2010)'ye göre öğretmen adaylarının okuma stratejilerini kullanma bakımından katılımcılar orta düzeyde olmakla birlikte, okuma stratejileri açısından en üst düzeyde olan grup Türkçe, en düşük düzeydeki grup ise sosyal bilgiler öğretmen adayları olduğu belirlenmiştir. Babacan (2012)'n araştırmasında ise sınıf öğretmeni adaylarının; üstbilişsel okuma stratejilerinin her iki boyutunu (analitik stratejiler ve pragmatik stratejiler) da sık sık kullandıklarını, pragmatik okuma stratejileri ile mantıksal zekâ alanı arasında bir ilişki olduğunu tespit etmiştir. Nitekim Karasakaloğlu (2012)'nun, sınıf öğretmeni adayları üzerinde yaptığı araştırmada üst bilişsel okuma stratejilerinden analitik okuma stratejilerini kullanma düzeyleri arttıkça okuduğunu anlama stratejilerini kullanma düzeylerinin de arttığı, analitik okuma stratejilerinin \%67,8'i tutum; pragmatik okuma stratejilerinin ise $\% 49,7$ tutum ve çalışma yardımcılarının açıkladığ 
görülmüştür. Bu sonuçlar üst bilişsel becerilerin bilgiye sahip olmanın ötesine geçerek bu bilgiyi aktif bir şekilde dönüştürerek kullanmayı gerektiren beceriler olduğunu destekler nitelikte olup okuma ve beraberinde anlamlandırma sürecindeki önemli bir etkiye sahip olduğunu ortaya koymaktadır.

Araştırma sonuçlar, etkiler açısından değerlendirildiğinde tüm örnekleme ilişkin modelde üst bilişsel okuma stratejilerinin, okuma motivasyonu üzerinde yüksek düzeyde bir etkiye sahip olduğu görülmüştür. Bu etki sınıf düzeyleri açısından değerlendirildiğinde 1. sinıflara ve 4. sınıflara ilişkin modelde üst bilişsel okuma stratejileri, okuma motivasyonu üzerinde yüksek bir etkiye sahipken 2. ve 3. sınıf düzeyinde bu etkinin anlamsız olduğu görülmüştür. Buradan hareketle 2. ve 3. sınıf düzeyinde Türkçe öğretmeni adaylarının okuma motivasyonlarını belirlemede üst bilişsel okuma stratejilerinin kullanımından daha etkili başka değişkenlerin olduğu ve okuma motivasyonlarının arttırılmasında, üst bilişsel okuma stratejilerinin doğrudan etkili olmadığı belirlenmiştir. 4. sınıf düzeyinde üst bilişsel okuma stratejileri kullanımının, okuma motivasyonu üzerinde en etkili sınıf düzeyi olduğu, bu etkinin 1. sınıf düzeyine göre daha yüksek ve etkili olduğu şeklinde yorumlanabilir. İlgili alan yazında sınıf düzeyine ilişkin böyle bir değerlendirmeye rastlanılmamakla birlikte sonuçlara üst bilişsel beceriler açısından bakıldığında; Karasakaloğlu ve diğerlerinin (2012) araştırmasında da strateji kullanımının sınıf düzeyine göre anlamlı olarak farklılaştığı tespit edilmiştir. Çöğmen (2008)'in araştırmasında, 1. ve 4. sınıfta öğrenim gören öğretmen adaylarının, üst bilişsel okuma stratejileri kullanımları manidar düzeyde farklılaşmaktadır. Her iki araştırmada 4. sınıftaki bu farklılaşmaya ilişkin sonuçlara ek olarak Karasakaloğlu ve diğerleri (2012), 4. sınıftaki Türkçe öğretmeni adaylarının strateji kullanımında daha yüksek puanlara sahip oluşunda fakültede işe koşulan program içeriklerinin ve öğretim elemanlarının gerçekleştirdiği etkinliklerden kaynaklandığını belirtmektedir. Ayrıca 4. sınıftaki bu farklılaşmada öğretmen adaylarının KPSS sınavına hazırlanma sürecinin getirdiği yoğun bir çalışma temposunun etkili olduğu düşünülebilir. Sınıf düzeyindeki bu farklılaşmaya rağmen alan yazında Çeçen ve Alver (2011)'in Türkçe öğretmeni adaylarıyla yaptığı araştırmada; Aybek ve Aslan (2016)'in ve Çöğmen (2008)'in araştırmasında da öğretmen adaylarının üst bilişsel okuma stratejilerini sıklıkla kullandıkları tespit edilmiştir. Ayrıca Çöğmen (2008)'in araştırmasında öğretmen adaylarının ders metinlerini okurken üst bilişsel okuma stratejilerini (analitik ve pragmatik okuma stratejilerini) kullandıkları, Türkçe öğretmen adaylarının ise analitik stratejileri daha sık kullandıkları belirlenmiştir. Çeçen ve Alver (2011)'in araştırmasında Türkçe öğretmeni adaylarının üst bilişsel okuma stratejileri kullanma sıklıkları "analitik stratejiler" boyutunda istatistiksel olarak birinci sinıflar lehine manidar farklılık gösterirken "pragmatik stratejiler" boyutunda benzer olduğu sonucuna ulaşılmıştır. Sınıf düzeyi açısından bu farklılıklar yanında alan yazındaki araştırma sonuçlarına göre analitik stratejilerin daha çok kullanıldığı söylenebilir (Akif ve Alver, 2011; Vianty (2007). Bu veriler de bize öğretmen adaylarının okuduğunu anlama sırasında bilişsel süreçleri içeren stratejiler olarak değerlendirilen analitik staratejileri, bilgiyi hatırlamayı ön plana çıkaran pragmatik stratejilerden daha çok kullandıklarını göstermektedir. Öğretmen adaylarının pragmatik stratejileri daha çok kullandığına ilişkin araştırmalarda (Babacan, 2012) mevcut olmakla birlikte bu sonuçlardan hareketle analitik stratejilerin 
kullanımının daha ön planda olduğu söylenebilir. Aybek ve Aslan (2016)'ın araştırmasında da öğretmen adaylarının üst bilişsel okuma stratejilerini kullanma düzeyleri sınıf düzeyine göre farklılık göstermediği, Kana (2015)'nın araştırmasında Türkçe öğretmeni adaylarının öğrenim gördükleri sınıf düzeyiyle motivasyonel, bilişsel ve bilişüstü yeterlikleri arasında istatistiksel olarak anlamlı bir farkın olmadığı görülmüştür. Bu sonuçlardan hareketle bu araştırma sonuçları değerlendirildiğinde sınıf düzeyine göre üstbilişsel okuma stratejileri ve okuma motivasyonun etki düzeyinin değiştiği ve bu etkinin açığa çıkışında sınıf düzeyindeki değişimin farklı faktörlerden etkilendiği söylenebilir.

Araştırma sonuçları cinsiyete ilişkin modeller açısından değerlendirildiğinde; erkek öğretmen adaylarına ilişkin modelde üst bilişsel okuma stratejilerinin, okuma motivasyonunu yüksek bir etkiye sahip olduğu; kadın öğretmen adayların ilişkin modelde ise bu etkinin anlamsız olduğu görülmüştür. Bu bulgulardan hareketle erkek öğretmen adaylarının üst bilişsel okuma strateji kullanımı arttıkça okumaya ilişkinin motivasyonlarının arttığı ve bu artışta üst bilişsel okuma stratejilerinin okuma motivasyonu üzerinde çok yüksek düzeyde pozitif bir etki oluşturduğu söylenebilir. İlgili alan yazında üst bilişsel okuma stratejilerinin, okuma motivasyonu üzerindeki etkisinde cinsiyetin rolünü inceleyen bir araştırmaya erişilememekle birlikte araştırmalara üst bilişsel strateji kullanımı açısından bakıldığında; Çeçen ve Alver (2011)'e göre Türkçe öğretmeni adaylarının üst bilişsel okuma stratejilerini kullanma sıklıkları cinsiyete göre "analitik stratejiler" boyutunda istatistiksel olarak manidar düzeyde bir fark göstermezken "pragmatik stratejiler" boyutunda kadın öğretmen adayları lehine manidar düzeyde farklılık göstermektedir. EdizerÇetinkaya (2015)'nın araştırmasında Türkçe öğretmen adaylarının, Aybek ve Aslan (2016)'ın araştırmasında öğretmen adaylarının üst bilişsel okuma stratejileri, Ateş (2013)'in araştırmasında üniversite öğrencilerinin okuma stratejileri üst bilişsel farkındalık düzeyleri kadınlar lehine manidar düzeyde farklılaşmaktadır. Bu araştırmaların aksine Hong (2008), Kummin ve Rahman (2010), Sonleitner (2001), Sheorey ve Mokhtari (2001)'nin araştırmalarında ise üst bilişsel okuma stratejilerini kullanmaları cinsiyet açısından benzer sonuçlara sahiptir. Mert (2015)'in araştırmasında ise okuma stratejilerine ilişkin bilişsel farkındalık düzeylerinde cinsiyetin bir etkisi olmadığı belirlenmiştir. Alan yazındaki araştırmalara okuma motivasyonu açısından bakıldığında ise kadın öğretmen adaylarının okuma motivasyonlarının, erkek öğretmen adaylarından daha yüksek olduğu tespit edilmiştir (Karahan, 2015; Savaşkan ve Özdemir, 2017). $\mathrm{Bu}$ sonuçlardan hareketle üst bilişsel okuma stratejileri kullanımında cinsiyet açısından tam bir değerlendirmeye varılamadığı, okuma motivasyonu açısından ise kadın öğretmen adaylarının daha yüksek motivasyona sahip olduğu söylenebilir. Sonuçlar tek değişken açısından bu araştırma sonuçlarıyla kıyaslandığında alan yazında kadın öğretmen adaylarının okuma motivasyonlarının yüksek oluşundan hareketle, kadın öğretmen adaylarının okuma motivasyonlarını etkileyen başka değişkenlerin bu süreçte daha etkili olduğu söylenebilir. Bu çıarım da bu araştırma sonucuyla örtüşmektedir. Bu sonuçlara göre de erkek öğretmen adaylarının okumaya motive olmalarında strateji kullanımın desteklenmesi gerektiği ve bunun da okuma motivasyonlarının artışında önemli etkiler oluşturacağı şeklinde değerlendirilebilir. 
Araştırmada elde edilen sonuçlar ve literatür bütün olarak değerlendirildiğinde okuma becerilerinin gelişimi ve okuma motivasyonunun artışı için üstbilişsel stratejilerin kullanımı bir gerekliliktir. Öğretmenlerin ve beraberinde öğretmen adaylarının bu stratejilere sahip olup bunları kendi birikimleriyle daha da geliştirerek mesleki ve özel yaşamlarında kullanmaları eğitim ve öğretime olumlu katkılar sağlayacaktır. Özetle öğretmen adaylarının üstbilişsel stratejilerinin ve okuma motivasyonlarının geliştirilmesi için öğretmen yetiştirme programları bu duyuşsal değişkenlerin sürece doğrudan dahil edilmesine olanak verecek şekilde güncellenmelidir.

\section{Uygulamaya Yönelik Öneriler}

1. Dil becerileriyle direk ilişkili olan üst bilişsel okuma stratejilerinin, Türkçe dersinde aktif olarak kullanımı için bu stratejilerin ilişkin modellemeler yoluyla bu stratejilerin uygulamalı olarak kullanımı sağlanmalıdır.

2. Okuma eğitimi dersinin içeriği gözden geçirilerek okuma ve üstbilişsel okuma stratejilerinin kullanımı için çeşitli çalışmalar ve çalıştaylar düzenlenerek dersin içeriği yeniden düzenlenebilir.

3. Öğretmenlerin bu stratejilerin kullanımına ilişkin hizmet içi eğitimler verilebilir.

\section{Araștırmalara Yönelik Öneriler}

1. 1. ve 4. sınıf düzeyinde üst bilişsel okuma stratejilerinin kullanımının, okuma motivasyonu üzerinde yüksek bir etkiye sahipken, 2. ve 3. sınıf düzeyinde bu etkinin anlamsız oluşunun sebepleri ve bu iki sınıf düzeyinde okuma motivasyona etki eden değişkenler incelenebilir.

2. 4. sınıf düzeyinde üst bilişsel okuma stratejilerinin kullanımının en yüksek düzeye ulaşmasının sebepleri incelenerek bu etkinin artış sebepleri tespit edilerek bu etkinin açığa çıkışını sağlayan değişkenlerin diğer sınıf düzeylerinde kullanımının etkileri incelenebilir.

3. Üst bilişsel okuma stratejilerinin, okuma motivasyonu üzerinde etkisine ilişkin oluşturulan bu model farklı örneklem üzerinde modelin geçerliliği sınanabilir.

4. Üst bilişsel okuma stratejilerinin etkileri yazma, konuşma ve dinleme becerileri üzerindeki etkileri incelenebilir.

\section{Kaynakça}

Aarnoutse, C., \& Schellings, G. (2003). Learning reading strategies by triggering reading motivation. Educational Studies, 29(4), 387-409.

Ahmadi, R. A., Ismail, H. N., \& Abdullah, M. K. (2013). The importance of metacognitive reading strategy awareness in reading comprehension. English Language Teaching, 6(10), 235-249.

Akca, Ç. (2008). İlköğretim ikinci kademe öğrencilerine kitap okuma alışkanlığı kazandırmada Türkçe ögretmenlerinin rolü. Yayımlanmamış yüksek lisans tezi. Yeditepe Üniversitesi, İstanbul.

Alvermann, D. E. (2009). Sociocultural constructions of adolescence and young people's literacies. L. Christenbury, R. Bomer ve P. Smagorinsky (Ed.), Handbook of adolescent literacy içinde (s. 14-28). New York, NY: Guilford. 
Akyol, H. (2007). Yeni programa uygun Türkçe öğretim yöntemleri. Ankara: Kök Yayıncllık.

Alsamadani, H. A. (2009). The relationship between Saudi EFL college-level students' use of reading strategies and their EFL reading comprehension. Retrieved from https://etd.ohiolink.edu/rws_ etd/document/get/ ohiou12 24685570/inline.

Anastasiou, D., \& Griva, E. (2009). Awareness of reading strategy use and reading comprehension among poor and good readers. İlköğretim Online, 8(2), 283-297.

Arıcı, A. F. (2008). Okumayı niye sevmiyoruz?: Üniversite öğrencileriyle mülakatlar. Mustafa Kemal Üniversitesi Sosyal Bilimler Enstitüsü Dergisi, 5(10), 91-100.

Ateş, A. (2013). Üniversite öğrencilerinin okuma stratejileri üstbilişsel farkındalık düzeyleri (İnönü Üniversitesi örneği). Uluslararası Türkçe Edebiyat Kültür Eğitim (TEKE) Dergisi, 2(4), 258-273.

Aybek, B., \& Aslan, S. (2016). Öğretmen adaylarının üstbilişsel okuma stratejilerinin çeşitli değişkenler açısından incelenmesi. The Journal of Academic Social Science Studies, 49, 533-546.

Babacan, T. (2012). Sını öğretmeni adaylarının üstbilişsel okuma stratejileri ile çoklu zekâ alanları arasındaki ilişkinin incelenmesi. Yayımlanmamış yüksek lisans tezi. Cumhuriyet Üniversitesi, Eğitim Bilimleri Enstitüsü, Sivas.

Baki, Y. (2018). The effect of reading motivations of 6th, 7th and 8th grade students on reading attitudes: A structural equation modeling. International Online Journal of Educational Sciences, 10(1).

Bang, H. J., \& Zhao, C.G. (2007). Reading strategies used by advanced Korean and Chinese ESL graduate students: A case study. The Reading Matrix, 7(1), 30-50.

Başaran, M. (2013). 4. sınıf öğrencilerinin üstbilişsel okuma stratejilerini kullanma durumları ve bu stratejilerle okuduğunu anlama arasındaki ilişki. Turkish Studies - International Periodical For The Languages, Literature and History of Turkish or Turkic, 8(8), 225-240.

Baydık, B. (2011). Okuma güçlüğü olan öğrencilerin üstbilişsel okuma stratejilerini kullanımı ve öğretmenlerinin okuduğunu anlama öğretim uygulamalarının incelenmesi. Eğitim ve Bilim, 36(162), 301-319.

Blakey, E., \& Spence, S. (1990). Developing metacognition. Syracuse, NY: ERIC Information Center Resources [ED327218].

Boulware-Gooden, R., Carreker, S., Thornhill, A., \& Joshi, M. (2007). Instruction of Metacognitive strategies enhances reading comprehension and vocabulary achievement of third-grade students. The Reading Teacher, 61, 70-77.

Bozkurt, M. (2013). Beşinci sınıf öğrencilerinin üstbilişsel okuduğunu anlama farkındalı̆̆ı ve okuma motivasyonları ile okuma düzeyleri arasındaki ilişki. Yayımlanmamış yüksek lisans tezi. Bülent Ecevit Üniversitesi, Sosyal Bilimler Enstitüsü, Zonguldak.

Bozkurt, M., \& Memiş, A. (2015). Beşinci sınıf öğrencilerinin üstbilişsel okuduğunu anlama farkındalı̆̆ı ve okuma motivasyonları ile okuma düzeyleri arasındaki ilişki. Ahi Evran Üniversitesi Kırşehir Eğitim Fakültesi Dergisi, 14(3), 147-160.

Butler, D. L., Cartier, S. C., Schnellert, L., Gagnon, F., \& Giammarino, M. (2011). Secondary students' selfregulated engagement in reading: Researching self-regulation as situated in context. Psychological Test and Assessment Modeling, 53, 73-105.

Cantrell, S. C., Almasi, J. F., Rintamaa, M., \& Carter, J. C. (2016). Supplemental reading strategy instruction for adolescents: A randomized trial and follow-up study. The Journal of Educational Research, 109(1), 7-26. 
Caron, A. A. (1997). Instruction of community college developmental readers in the awareness and use of metacognitive strategies using the think-aloud heuristic, Unpublished doctoral dissertation, University of Central Florida, Orlando.

Ciardiello, A. V. (Nov 1998). "Did you ask a good question today? Alternative cognitive and metacognitive strategies" Journal of Adolescent \& Adult Literacy, 42 (3), 210-220.

Corbin, B. (2008). Unleashing the potential of the teenage brain: 10 powerful ideas. Thousand Oaks, CA: Corwin Press.

Costa, L. A., \& Lowery, L. F. (1989). Techniques for teaching thinking, midwest publications. Alexandria, USA.

Çakıroğlu, A. (2007). Üstbilişsel strateji kullanımının okuduğunu anlama düzeyi düşük öğrencilerde erişi artırımına etkisi. Yayımlanmamış doktora tezi. Gazi Üniversitesi, Eğitim Bilimleri Enstitüsü, Ankara.

Çakıroğlu, A., \& Ataman, A. (2008). Üstbilişsel strateji öğretiminin okuduğunu anlama başarı düzeyi düşük öğrencilerde erişi artırımına etkisi. Sakarya Üniversitesi Eğitim Fakültesi Dergisi, (16), 1-13.

Çeçen, M. A., \& Alver, M. (2011). Türkçe öğretmeni adaylarının üstbilişsel okuma stratejilerini kullanma düzeyleri (Giresun Üniversitesi örneği). Karadeniz Sosyal Bilimler Dergisi, 3(5), 39-56.

Çetinkaya P., \& Ertkin E (2002). Assessment of metacognition and its relationship with reading comprehension, achievement, and aptitude. Boğaziçi University Journal Education, 19(1), 1-11.

Çiçekçioğlu, D. (2003). Bilişsel ve biliş ötesi okuma stratejilerinin direk ve tümleşik olarak bilinçlendirme seviyesinde öğretiminin okuma yeterliliğine ve strateji kullanımına etkileri. Yayımlanmamıs yüksek lisans tezi. Ortadoğu Teknik Üniversitesi, Sosyal Bilimler Enstitüsü, Ankara.

Çöğmen, S. (2008). Eğitimfakültesiöğrencilerinin kullandıkları okuduğunu anlamastratejileri. Yayımlanmamış yüksek lisans tezi. Adnan Menderes Üniversitesi, Sosyal Bilimler Enstitüsü, Aydın.

Çöğmen, S., \& Saracaloğlu, A. S. (2010). Üst bilişsel okuma stratejileri ölçeğinin Türkçeye uyarlama çalışmaları. Pamukkale Üniversitesi Ĕ̆itim Fakültesi Dergisi, 28(28), 91-99.

De Naeghel, J., Van Keer, H., \& Vanderlinde, R. (2014). Strategies for promoting autonomous reading motivation: A multiple case study research in primary education. Frontline Learning Research, 2(1), 83-101.

Demir-Gülşen, M. (2000). A model to investigate probability and mathematics achievement in terms of cognitive, metacognitive and affective variables. Unpublished master thesis. Boğaziçi University, The Institute of Science and Engineering, İstanbul.

Dhanapala, K. V., \& Hirakawa, Y. (2016). L2 reading motivation among Sri Lankan university students. Reading Psychology, 37(2), 202-229.

Dülger, O. (2007). Bilişötesi stratejilerin yazma becerilerinin geliştirilmesinde tutum, erişi ve kalıcılğga etkisi. Yayımlanmamış doktora tezi. Selçuk Üniversitesi, Sosyal Bilimler Enstitüsü, Konya.

Dilci, T., \& Kaya, S. (2012). Examination of meta-cognitive awareness levels of class teachers teaching 4th and 5th grades in terms of various variables. SDU Faculty of Arts and Sciences Journal of Social Sciences, 27, 247-267.

Edizer-Çetinkaya, Z. (2015). Türkçe öğretmen adaylarının kitap okuma alışkanlığına ilişkin tutumları ile üst bilişsel okuma stratejilerini kullanım düzeyleri arasındaki ilişki. Kastamonu Eğitim Dergisi, 23(2), 645-658.

Eker, C. (2014). The effect of teaching practice conducted by using metacognition strategies on students' reading comprehension skills. International Online Journal of Educational Sciences, 6(2), 269-280.

Flavell, J. H. (1979). Metacognition and cognitive monitoring: A new area of cognitive-developmental inquiry. American Psychologist, 34, 906-911. 
Gelen, İ. (2003). Bilişsel farkındalık stratejilerinin Türkçe dersine ilişkin tutum, okuduğunu anlama ve kalıcıliğa etkisi. Çukurova Üniversitesi Sosyal Bilimler Enstitüsü. Yayınlanmamış Doktora Tezi: Adana.

Gelen, İ. (2004). Bilişsel farkındalık stratejilerinin Türkçe dersine ilişkin tutum, okuduğunu anlama ve kalıcılığa etkisi. XIII. Ulusal Eğitim Bilimleri Kurultayı, 6-9 Temmuz 2004, İnönü Üniversitesi, Eğitim Fakültesi, Malatya.

Guthrie, J. T., \& Wigfield, A. (2000). Engagement and motivation in reading. In M. Kamil, P. B. Mosenthal, P. D. Pearson, R. Barr (Eds.), Reading Research Handbook (3, 403-424). Mahwah, NJ: Erlbaum.

Guthrie, J. T., \& Wigfield, A. (2005). Roles of motivation and engagement in reading comprehension assessment. In S., G. Paris \& S., A. Stahl (Eds.), Children's reading comprehension and assessment (s. 187-214), Mahwah, NJ: Lawrence Erlbaum Associates.

Guthrie, J. T., Klauda, S. L., \& Ho, A. N. (2013). Modeling the relationships among reading instruction, motivation, engagement, and achievement for adolescents. Reading Research Quarterly, 48(1), 9-26.

Guo, Y., \& Roehrig, A. D. (2011). General versus second language specific knowledge in the English reading comprehension of Chinese-speaking learners. Reading in a Foreign Language, 23(1), 42-64.

Günay, D. (2003). Metin bilgisi. İstanbul: Multilingual Yayınları.

Hall, K., \& Myers, J. (July 1998), That's just the way I am': Metacognition, personal intelligence and reading, Blackwell Pub., Oxford, UK, and MA, USA.

Hall, K., \& Bowman, H. (1999). Metacognition and reading awareness among samples of nine-year-olds in two cities. Educational Research, 14(1), 100-104.

Hassan, F. (2003). Metacognitive strategy awareness and reading comprehension. Universiti Putra, Malaysia.

Hong, Z. (2008). The metacognitive awareness of reading strategies among english major and nonenglish majora college students in southern Taiwan. Unpublished master thesis. Gradute Studies of Leader University, Taiwan.

Hu, L., \& Bentler, M. (1999). Cutoff criteria for fit indexes in covariance structure analysis: conventional criteria versus new alternatives. Structural Equation Modeling: A Multidisciplinary Journal, 6(1), 1-55.

Housand, A., \& Reis, S. M. (2008). Self-regulated learning in reading: Gifted pedagogy and instructional setting. Journal of Advanced Academics, 20, 108-136.

Ilustre, C. A. (2011). Beliefs about reading, metacognitive reading strategies and text comprehension among college students in a private university. Philippine ESL Journal, 7(July 2011), 28-47.

Ismail, N. M., \& Tawalbeh, T. I. (2015). Effectiveness of a metacognitive reading strategies program for improving low achieving EFL readers.International Education Studies, 8(1), 71-81.

İflazoğlu Saban, A., \& Saban, A. (2008). Sınıf öğretmenliği öğrencilerinin bilişsel farkındalıkları ile güdülerinin bazı sosyo-demografik değişkenlere göre incelenmesi. Ege Eğitim Dergisi, 9(1), 35-58.

İskender, H. (2013). Türkçe öğretmenlerinin okuma ilgileri ve öğrencilere okuma alışkanlığı kazandırmaya yönelik etkinlikleri üzerine bir araştırma: Trabzon ili örneği. Yayınlanmamış yüksek lisans tezi. Karadeniz Teknik Üniversitesi, Eğitim Bilimleri Enstitüsü, Trabzon.

Jafari, S. M., \& Shokrpour, N. (2012). EAP students' reading motivation of English academic expository texts: A mixed methods design. International Journal of Linguistics, 4(4), 372-392.

Jamshidi, P., \& Moghaddam, M. Y. (2013). The effect of Iranian EFL learners' awareness of reading comprehension strategies on their motivation to read. International Journal of English Language Education,1(1), 162-178. 
Jou, Y. J. (2014). Investigation of technological university students' use of metacognitive reading strategies in first and second languages. English Language Teaching, 8(1), 180-187.

Jöreskog, K. G., \& Sörbom, D. (1993). Lisrel 8: Structural equation modeling with the simplis command languange. Scientific Software İnternational, Inc. USA.

Justice, E.M. and Dornan, T. M. (2001). Metacognitive differences betweer traditional age and nontraditional age college students. Adult Education Quarterly, 51, 236-249.

Kana, F. (2015). Türkçe öğretmeni adaylarının motivasyonel, bilişsel ve bilişüstü yeterlikleri. Uluslararası Ĕ̆itim Bilimleri Dergisi, 2(4), 395-407.

Karabay, A. (2015). Eleştirel okuma eğitiminin üst bilişsel okuma stratejileri ve medya okuryazarlığı üzerindeki etkisi. Eğitimde Kuram ve Uygulama, 11(4), 1167-1184.

Karadağ, R. (2014). Okuma ilgisi, tutumları ve alışkanlığı konusunda yapılmış çalışmaların lisansüstü tezlere dayalı analizi: YÖK ve Proquest veri tabanları örneklemi. Pamukkale Üniversitesi Eğitim Fakültesi Dergisi, 35(1), 1-17.

Karahan, B. Ü. (2015). Öğretmen adaylarının okumaya yönelik motivasyonlarının çeşitli değişkenler açısından incelenmesi (Kafkas Üniversitesi Örneği). Electronic Turkish Studies, 10(11), 1569-1586.

Karasakaloğlu, N. (2012). Sınıf öğretmeni adaylarının okuduğunu anlama stratejileri ile öğrenme ve ders çalışma stratejileri arasındaki ilişki. Kuram ve Uygulamada Eğitim Bilimleri (KUYEB), 12(3), 19211950.

Karasakaloğlu, N., Karacaloğlu, A. S., \& Özelçi, S. Y. (2012). Türkçe öğretmeni adaylarının okuma stratejileri, eleştirel düşünme tutumları ve üst bilişsel yeterlilikleri. Ahi Evran Üniversitesi Kırşehir Eğitim Fakültesi Dergisi, 13(1), 207-221.

Karasar, N. (2005). Bilimsel araştırma yöntemi. Ankara: Nobel Yayın Dağıtım.

Kışkır, G. (2011). Öğretmen adaylarının bilişötesi farkındalık düzeyleri ile problem çözme becerileri arasındaki ilişkinin incelenmesi. Yayımlanmamış yüksek lisans tezi. Atatürk Üniversitesi Eğitim Bilimleri Enstitüsü, Erzurum.

Klem, L. (2000). Structural equation modeling. L. Grimm ve P. Yarnold (Eds.), Reading and understanding multivariate statistics (Vol. II). Washington, DC: American Psychological Association.

Kline, R. B. (2011). Principles and practice of structural equation modeling. New York and London: The Guilford Press.

Komiyama, R. (2013). Factors underlying second language reading motivation of adult EAP students. Reading in a Foreign Language, 25(2), 149-169.

Korotaeva, I. V. (2012). Metacognitive strategies in reading comprehension of education majors. ProcediaSocial and Behavioral Sciences, 69(2012), 1895-1900.

Kummin, S., \& Rahman, S. (2010). The relationship between the use of metacognitive strategies and achivement in English. Procedia-Social and Behavioral Sciences, 7, 145-150.

Manguel, A. (2004). Okumanın tarihi. (F. Elioğlu, Çev.). İstanbul: YKY. (A history of reading, 1997).

Manning, B. H., \& Glasner, S. E. (1996). The self-regulated learning aspect of metacognition: a component of gifted education. Roeper Review, 18(3), 217-224.

Mayer, R. E. (1998). Cognitive, metacognitive and motivational aspects of problem solving. Instructional Science, 26, 49-63.

McGeown, S. P., Johnston, R. S., Walker, J., Howatson, K., Stockburn, A., \& Dufton, P. (2015). The relationship between young children's enjoyment of learning to read, reading attitudes, confidence and attainment. Educational Research, 57(4), 389-402. 
Mehrdad, A. G., Ahghar, M. R., \& Ahghar, M. (2012). The effect of teaching cognitive and metacognitive strategies on EFL students' reading comprehension across proficiency levels. Procedia-Social and Behavioral Sciences, 46, 3757-3763.

Memiş, A., \& Bozkurt, M. (2013). The relationship of reading comprehension success with metacognitive awareness, motivation, and reading levels of fifth grade students. Global Journal of Educational Foundation, 1(1), 034-038.

Meniado, J. C. (2016). Metacognitive reading strategies, motivation, and reading comprehension performance of saudi EFL students. English Language Teaching, 9(3), 117.

Mert, E. L. (2015). Türkçe öğretmen adaylarının okuma stratejilerine ilişkin bilişsel farkındalık düzeyleri. Erzincan Üniversitesi Sosyal Bilimler Enstitüsü Dergisi, 9(2), 95-106.

Meydan, C. H., \& Şeşen, H. (2011). Yapısal eşitlik modellemesi AMOS uygulamaları. Ankara: Detay Yayıncılık.

Mokhtari, K., \& Reichard, C. A. (2002). Assessing students' metacognitive awareness of reading strategies. Journal of Educational Psychology, 94, 249-259.

Mokhtari, K., \& Reichard, C. A. (2002). Assessing students' metocognitive awareness of reading strategies. Journal of Educational Psychology, 94(2), 249-259.

Muhtar, S. (2006). Üstbilişsel strateji eğitiminin okuma becerisinde öğrenci başarısına olan etkisi. Ankara Üniversitesi Sosyal Bilimler Enstitüsü, Yayımlanmamış yüksek lisans tezi, Ankara.

Ormrod, J. E. (2003). Educational psychology. New Jersey: Merill Prentice Hall.

Özbilgin, A. (1993). Effects of university EFL students in metacognitive strategies for listening to academic lectures. Unpublished master thesis. Bilkent University, The Institute of Economics and Social Sciences, Ankara.

Özcan, Z, Ç. (2007). Sınıf öğretmenlerinin derslerinde biliş üstü beceri geliştiren stratejileri kullanma özelliklerinin incelenmesi. Yayınlanmamış doktora tezi. Marmara Üniversitesi, Eğitim Bilimleri Enstitüsü, İstanbul.

Öztürk, E. (2012). The validity and reliability of the Turkish version of the metacognitive awareness of reading strategies inventory. İlköğretim Online, 11(2), 292-305.

Öztürk, E., \& Uzunkol, E. (2015). İlköğretim 4. sınıföğrencilerinin okuma stratejileri üstbilişsel farkındalıkları ve okuma motivasyonlarının değerlendirilmesi. Turkish Studies, 10(7), 803-814.

Pammu, A., Amir, Z., \& Maasum, T. (2014). Metacognitive reading strategies of less proficient tertiary learners: A case study of EFL learners at a public university in Makassar, Indonesia. ProcediaSocial and behavioral Scences, 118, 357-364.

Paris, S. G., \& Winograd, P. (1990). How metacognition can promote academic learning and instruction. Ed: B. F. Jones and L. Idol, Dimensions of Thinking and Cognitive Instruction (pp. 15-51). Hillsdale, NJ: Erlbaum.

Pei, L. (2014). Does metacognitive strategy instruction indeed improve Chinese EFL learners' reading comprehension performance and metacognitive awareness? Journal of Language Teaching and Research, 5(5), 1147-1152.

Peirce, W. (2004). Metacognition: Study strategies, monitoring, and motivation. a greatly expanded text version of a workshop presented. November 17, 2004, at Prince George’s Community College.

Raykov, T., \& Marcoulides, G. A. (2008). An introduction to applied multivariate analysis. Taylor \& Francis Group, LLC.

Pressley, M. (1990). Cognitive strategy instruction that really improves children's academic performances. Cambridge, MA: Brookline Books. 
Roeschl-Heils, A., Schneıder, W. \& Van Kraayenoord, C. E. (2003). Reading, metacognition and motivation: A follow-up study of German students in grades 7 and 8. European Journal of Psychology of Education, 18(1), 75-86.

Ryan, R. M., \& Deci, E. L. (2000). Self-determination theory and the facilitation of intrinsic motivation, social development, and well-being. American Psychologist, 55, 68-78.

Saraç, S. (2010). İlköğretim beşinci sınıf öğrencilerinin üstbiliş düzeyleri, genel zekâ ve okuduğunu anlama düzeyleri arasındaki ilişkinin incelenmesi. Yayımlanmamı̧ doktora tezi. Marmara Üniversitesi, Eğitim Bilimleri Enstitüsü, İstanbul.

Sarı, A., \& Akınoğlu, O. (2009). Öz-düzenlemeli öğrenme: Modeller ve uygulamalar. M. Ü. Atatürk Eğitim Fakültesi Eğitim Bilimleri Dergisi, 29, 139-154.

Sarı, A., \& Akınoğlu, O. (2009). Öz-düzenlemeli öğrenme: Modeller ve uygulamalar. Marmara Üniversitesi Atatürk Eğitim Fakültesi Eğitim Bilimleri Dergisi, 29, 139-154.

Savaşkan, V., \& Özdemir, A. (2017). Determining the variables that affect the reading motivation of educational faculty students. Educational Research and Reviews, 12(13), 660-676.

Sen, H. S. (2009). The relationship between the use of metacognitive strategies and reading comprehension. Procedia - Social and Behavioral Sciences, 1, 2301-2305.

Schaffner, E., Schiefele, U., \& Ulferts, H. (2013). Reading amount as a mediator of the effects of intrinsic and extrinsic reading motivation on reading comprehension. Reading Research Quarterly, 48(4), 369-385.

Schraw, G. (2002). Promoting general metacognitive awareness metacognition in learning and instruction. $\mathrm{H}$. J. Hartman (Ed.) Kluwer Academic Publischers, London.

Schutte, N. S., \& Malouff, J. M. (2007). Dimensions of reading motivation: Development of an adult reading motivation scale. Reading Psychology, 28(5), 469-489.

Sheorey, R., \& Mokhtari, K. (2001). Differences in the metacognitive awareness of reading strategies between native and nonnative readers. System: Journal of Applied Linguistics and Educational Technology, 29, 431-449.

Sonleitner, C. L. (2001). Metacognitive strategy use and its effect on college biology students' attitude toward reading in the content area. Unpublished master thesis. Oklahoma State University Bachelor of Science, USA.

Tavakoli, H. (2014). The effectiveness of metacognitive strategy awareness in reading comprehension: The case of Iranian university EFL students. The Reading Matrix, 14(2), 314-336.

Temizkan, M. (2008). Bilişsel okuma stratejilerinin Türkçe derslerinde bilgiye dayalı metinleri okuduğunu anlama üzerindeki etkisi. Gazi Üniversitesi Gazi Eğitim Fakültesi Dergisi, 28(2), 129-148.

Temizkan, M. (2007). İlköğretim ikinci kademe Türkçe derslerinde okuma stratejilerinin okuduğunu anlama üzerindeki etkisi. Yayımlanmamış doktora tezi. Gazi Üniversitesi, Eğitim Bilimleri Enstitüsü, Ankara.

Tice, T. N. (1991). Metacognition. Education Digest, 56(9), 27.

Topuzkanamiş, E., \& Maltepe, S. (2010). Öğretmen adaylarının okuduğunu anlama ve okuma stratejilerini kullanma düzeyleri. Journal of Türklük Bilimi Araştırmaları, 15(27), 655-677.

Yıldızlı, H., \& Saban, A. (2015). Özdüzenlemeli öğrenmeye kuramsal bir bakış. Uluslararası Eğitim Bilimleri Dergisi, 2(4), 97-118.

Unrau, N. J., \& Quirk, M. (2014). Clarifying the distinction between reading motivation and reading engagement. Reading Psychology, 35, 260-284. 
Ülper, H. (2011). Öğrenci açısından okumaya güdüleyici etmenler. Kuram ve Uygulamada Eğitim Bilimleri, $11(2), 941-960$.

Van Kraayenoord, C. E., \& Schneider, W. E. (1999). Reading achievement, metacognition, reading selfconcept and interest: A study of German students in grades 3 and 4. European Journal of Psychology of Education, 14(3), 305-324.

Wang, M. T. (2009). Effects of metacognitive reading strategy instruction on efl high school students' reading comprehension, reading strategies awareness and reading motivation. unpublished doctoral thesis. Universty of Florida.

Watkins, M. W., \& Coffey, D. Y. (2004). Reading motivation: Multidimensional and indeterminate. Journal of Educational Psychology, 96, 110-118.

Weir, C. (1998). Using embedded questions to jumpstart metacognition in middle school remedial readers. Journal of Adolescent \& Adult Literacy, 41 (6), 458-467.

Wright, J., \& Jocobs, B. (2003). Teaching phonological awareness and metacognitive strategies to children with reading difficulties: A comparison of two instructional methods. Educational Psychology, 23,(1).

Wigfield, A., \& Guthrie, J. T. (1997). Relations of children's motivation for reading the amount and breadth of their reading. Journal of Educational Psychology, 89 (3), 420-432.

Winne, P. H., \& Perry, N. E. (2000). Measurig self-regulated learning. In M. Boekaerts, P. Pintrich ve M. Zeidner (Eds.), Handbook of self-regulation (pp. 531-566). Orlando. FL: Academic Pres.

Yıldız, M., Yıldırım, K., Ateş, S., \& Çetinkaya, Ç. (2013). Yetişkin okuma motivasyonu ölçeğinin Türkçe uyarlaması. Elektronik Sosyal Bilimler Dergisi, 44(44), 348-359.

Yüksel, I., \& Yüksel, I. (2012). Metacognitive awareness of academic reading strategies. Procedia-Social and Behavioral Sciences, 31, 894-898. 